\title{
Impact of Thermal Processing on the Nutrients, Phytochemicals, and Metal Contaminants in Edible Algae
}

Critical Reviews in Food Science and Nutrition (accepted manuscript)

DOI: $10.1080 / 10408398.2020 .1821598$

Kacie K.H.Y. Ho ${ }^{1}$ and Benjamin W. Redan ${ }^{2 *}$

1. Department of Human Nutrition, Food and Animal Sciences, College of Tropical Agriculture and Human Resources, University of Hawaii at Manoa

2. U.S. Food and Drug Administration, Center for Food Safety and Applied Nutrition, Bedford Park, IL

*To whom correspondence should be addressed. Email: benjamin.redan@fda.hhs.gov 


\begin{abstract}
Edible algae products have increasingly become a larger component of diets worldwide. Algae can be a source of essential micronutrients and bioactive phytochemicals, although select varieties also often contain elevated concentrations of heavy metal contaminants. Due to the effects thermal processing of foodstuffs can have on levels of nutrients, phytochemicals, and contaminants, it is important to consider the role processing has on the levels of these components in algae food products. Here, we evaluate the literature covering how different types of processing, including commercial thermal application and in-home preparation, affect constituents such as vitamins, minerals, carotenoids, pigment compounds, and metal contaminants. Overall, the literature suggests that there are optimum processing conditions and specific cooking techniques that can be used to increase retention of important nutritional components while also reducing concentrations of metal contaminants. Although further research is needed on how thermal processing affects individual compounds in algae and their ultimate bioavailability, these data should be taken into consideration in order to inform design of product processing to both increase retention of nutritional components and limit metal contaminants.
\end{abstract}

Keywords: Seaweed, carotenoids, vitamins, phenolic compounds, thermal processing, heavy metals 


\section{Introduction}

Archeological artifacts have indicated that humans have long been consuming algae as part of their diets. Indeed, written records documenting algae consumption in China have existed for more than two millennia, but perhaps its earliest reported use dates back to over 12,000 years ago in what is now modern-day Chile (Dillehay et al. 2008, Bangmei and Abbott 1987). More recently, the global algae industry has been growing at a rapid pace, with one projection estimating that the market will reach at least $\$ 50$ billion USD by 2027 , approximately $80-90 \%$ of which is related to products for human consumption (McHugh 2003, Grosshagauer, Kraemer, and Somoza 2020). Of the algae-based food products, $40 \%$ are consumed in a relatively unprocessed form recognizable to consumers - such as dried sheets—with the remaining $60 \%$ as algae-derived food ingredients such as alginates, agar, and carrageenan (Wells et al. 2017). Whereas historically the consumption of algae has largely been consolidated to certain localized markets, particularly to the Asia Pacific region, areas such as the continental United States (US) and Western Europe have experienced an increasingly expanding market for algae and related products that incorporate algae as a major ingredient (Bouga and Combet 2015). As an indicator of this increase, there have been calls for changes in labeling regulations to highlight specific compounds found within algae (Bouga and Combet 2015).

Products that include edible algae have expanded globally as part of the evolving food industry's desire to satisfy the consumer's appetite for novel and functional products. For instance, studies conducted on Australian consumers suggest that algae-based foods have a potential growth opportunity in Western societies especially via populations in market segments who prioritize health, the environment, snacks, and new trends (Birch, Skallerud, and Paul 2019a, 2019b). Increased interest in algae-containing foods may be related to increased research 
documenting its content of micronutrients and potentially bioactive phytochemicals. This increased attention has led to changes in foods and dietary supplement formulations to incorporate algae to address market demand (Tanna and Mishra 2018, Haskell-Ramsay et al. 2018). For example, the seaweed kelp is widely used as a source of iodine (I) in various dietary supplements, and different types of algae (e.g., Spirulina and Dunaliella salina) are also incorporated into supplements due to high concentrations of pro-vitamin A carotenoids and other phytochemical constituents (Grosshagauer, Kraemer, and Somoza 2020, Hu et al. 2008). Aside from compounds with potentially beneficial effects on health endpoints, it is important to consider that algal organisms can also accumulate metal contaminants (Banach, Hoek-van den Hil, and van der Fels-Klerx 2020). The most prominent of these potential contaminants are the toxic heavy metals, including arsenic $(\mathrm{As})$, cadmium $(\mathrm{Cd})$, lead $(\mathrm{Pb})$, and mercury $(\mathrm{Hg})$ (Brandon, Janssen, and de Wit-Bos 2014, Hwang et al. 2010). Therefore, such products need to be viewed in its totality to fully characterize both the target nutrients of interest, in addition to any possible contaminants.

Regardless of the known phytochemicals or contaminants present in fresh, unprocessed algae, these products generally undergo several stages of processing before being consumed, as with many other types of foods (Li et al. 2019, Hamid et al. 2020). Consequently, it is critical to characterize how post-harvest processing, inclusive of storage, thermal processing, and in-home cooking, affects these nutrients, phytochemicals, and contaminants. Here, we first review the major types of whole algae food products consumed within diets, we describe the major nutrients, phytochemicals, and metal contaminants in these foods, and then finally evaluate the literature that describes how processing affects the concentrations of these constituents. As the focus of this review is on whole or algae-based products, this review will not include studies 
involving seaweed extracts or algae-derived ingredients. Still, it is important to recognize that ingredients derived from algae — hydrocolloids likely being the most well-known—are widespread in the food supply and provide critical functional attributes in multiple foods (Porse and Rudolph 2017).

\section{Algae varieties found in the diet}

Algae is a general term that can be used to describe aquatic organisms that are unicellular eukaryotes, multicellular eukaryotes, and prokaryotes, with specific examples including microalgae, seaweeds, and blue-green algae, respectively (Figure 1) (Hoek et al. 1995). To complicate matters, algae taxonomy is a field that is still developing, so it is not uncommon for organisms to have several different names and taxonomic classifications (Lim et al. 2017). The multiplicity of names may also be due partly to challenges in translating indigenous or traditional names into appropriate taxonomic terms (Abbott 1978). There are at least tens of thousands of varieties of algae, but only a small fraction of this number is consumed in the human diet. Over 70 species of algae have been reported in the Chinese diet and more than 50 in the Japanese diet, with roughly 20 of the species overlapping in both countries (Bangmei and Abbott 1987, Arasaki and Arasaki 1983). In addition, taxonomic names of multiple varieties of edible Hawaiian algae, including endemic species, have also been well documented (Abbott 1984). Information on per capita consumption of algae products is limited, as evidenced by data published by the Food and Agriculture Organization (FAO) which contains values for only three out of 163 countries in their database (FAO 2020). For the most recent year available (2013), per capita consumption of 


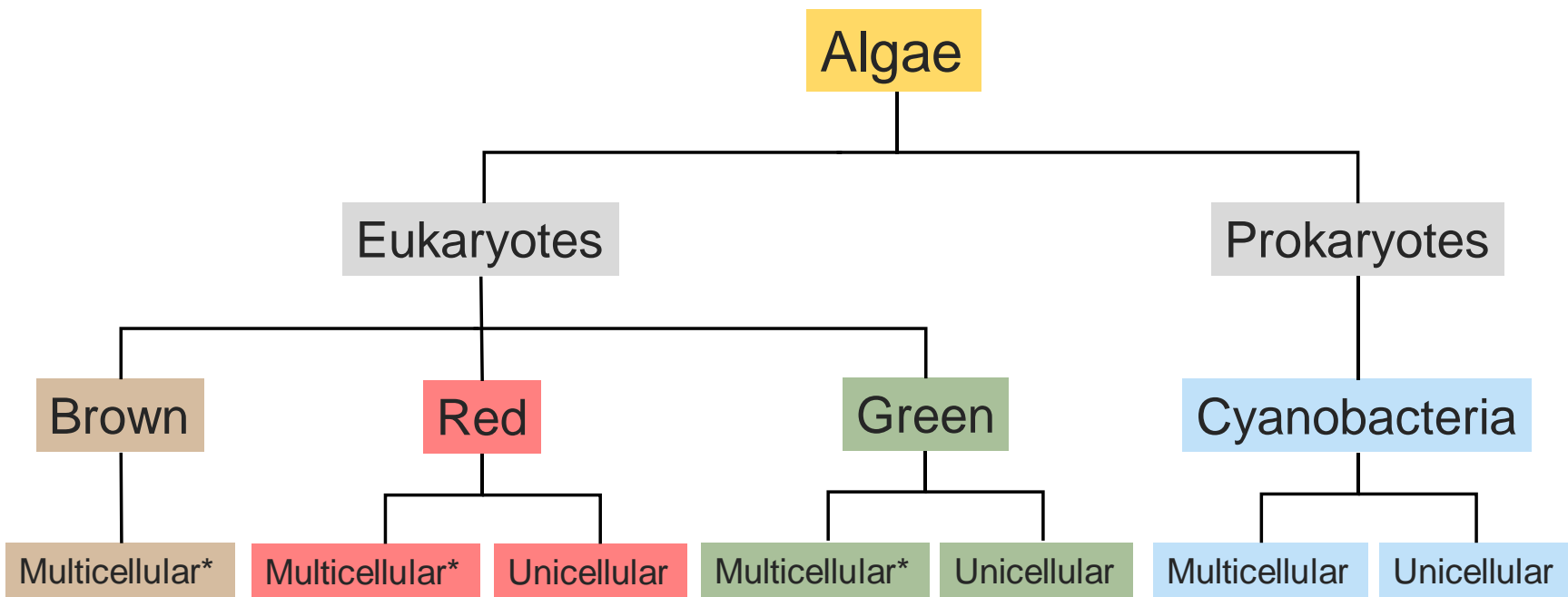

Figure 1. Overview of the types of organisms often referred to as algae. Prokaryotic cyanobacteria have previously been considered a type of algae, but more recently the term algae has been used to exclusively refer to eukaryotic species. *Multicellular, eukaryotic types of algae are commonly referred to as macroalgae or seaweed.

algae (or "aquatic plants") specify that Korea, China, and Japan consumed 61, 26, and 2.5 g per day, respectively.

Eukaryotic algae can be broadly described by its color or appearance as brown, green, or red (Figure 2). Most algae species with relevance to food are marine, but some types of green algae are found in freshwater or even on land. Brown algae are from class Phaeophyceae, which includes a group of kelps that are often referred to in the US by their Japanese common names such as kombu (Laminaria japonica) and wakame (Undaria pinnatifida). Different species of kelp may be used in dietary supplements as a source of micronutrients, used as a seasoning or prepared as a tea (e.g., kombu), or simply served with a meal as a vegetable (e.g., wakame) (Nisizawa et al. 1987). Green algae are classified within the phylum Chlorophyta and include organisms from genus Chlorella, which has been promoted as an environmentally-sustainable source of protein and can be found in dietary supplements (Safi et al. 2014). Red algae within the 
phylum Rhodophyta, include seaweed nori (Porphyra spp.) and dulse (Palmaria palmata).

Although disputed within the taxonomy field, algae terminology has often been inclusive of prokaryotes, such as cyanobacteria, which are known to exist across marine, freshwater, and terrestrial environments. More recently, an increasing number of biologists and taxonomists have considered algae to be inclusive of only eukaryotic organisms, but to avoid confusion, we will use the term algae to broadly include both eukaryotic species and prokaryotic cyanobacteria. Cyanobacteria from the genus Spirulina are currently commonly marketed as dietary supplements due to their high concentration of micronutrients and phytochemicals. However, Spirulina has a history of being a traditional source of food in various societies, including those in the region of West-central Africa surrounding Lake Chad (Hoek et al. 1995). Aside from Spirulina, cyanobacteria from marine (Brachytrichia quoyi) and terrestrial (Nostoc flagelliforme) environments have been commonly consumed in China (Bangmei and Abbott 1987).
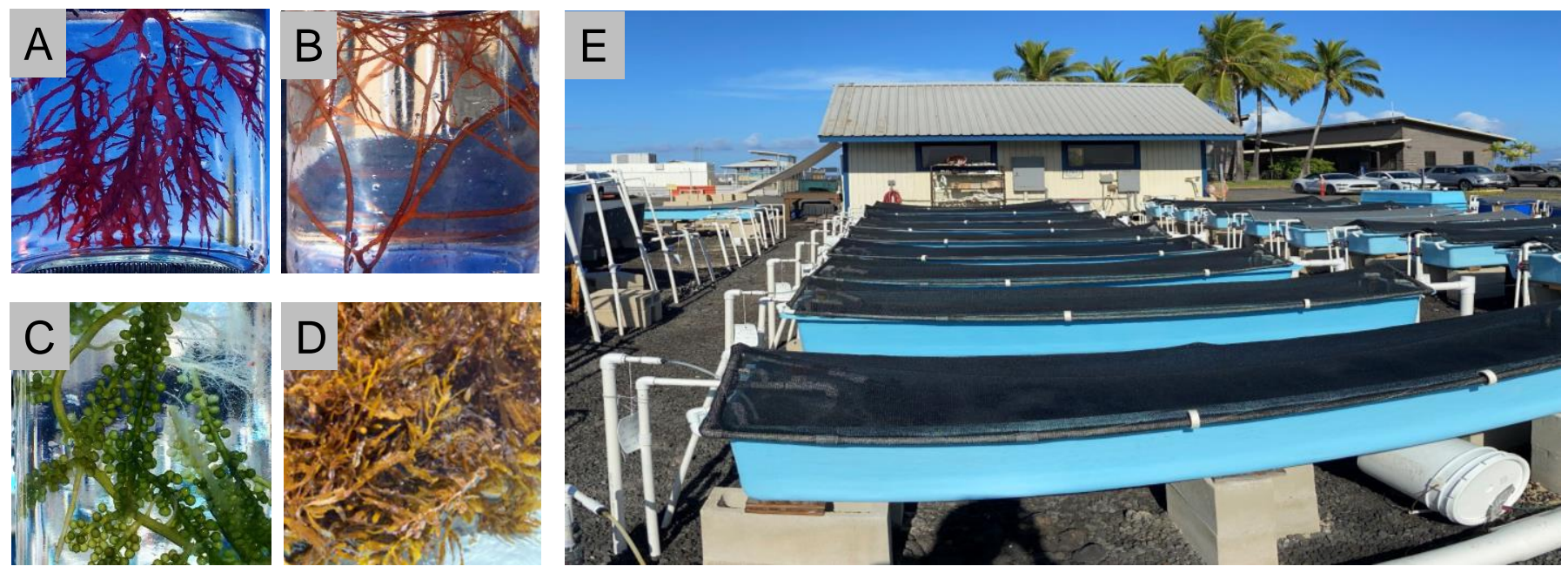

Figure 2. Examples of algae from Ocean Era's (formerly Kampachi Farms) research facility at the Natural Energy Laboratory of Hawaii Authority (NELHA) on the Big Island of Hawaii, US. (A) cultivated red algae (Halymenia hawaiiana), (B) cultivated red algae (Gracilaria parvispora), (C) cultivated green algae (Caulerpa lentillifera), (D) wild-collected brown algae (Sargassum spp.) and (E) Ocean Era's land-based tank array system for tropical macroalgae culture. Photos taken by Keelee Martin (๑) Ocean Era, LLC. Used with permission. 


\section{Overview of the post-harvest processing of algae}

Algae historically have been largely wild-harvested from bodies of water, but the increased demand of these products has driven producers to cultivate algae in more controlled environments (see Figure 1E). If strategically implemented, commercial production can also be leveraged to remediate depleted waters, combat invasive algal species, and reduce the burden on natural algae in locations with decreasing wild populations of algae (Hart et al. 2014, Li et al. 2020). Freshly harvested algae can be stored prior to consumption, although the high moisture content of the seaweed necessitates immediate processing or addition of a preservative such as mineral salts (e.g., sodium chloride) to prevent growth of spoilage organisms (Wang, Zhang, and Fang 2019). Some types of algae are commonly consumed fresh or unprocessed, such as ogo (Gracilaria spp.) and limu lipoa (Dictyopteris plagiogramma), which are commonly consumed in Hawaii, sea grapes (Caulerpa lentillifera) in Japan, and dulse (Palmaria palmata) in Ireland. However, the majority of commercial algae-based foods are processed prior to consumption.

There are several methods for post-harvest processing of algae, with different types of drying typically being most common (Santiago and Moreira 2020). Depending on climate, algae can be dried in the sun after harvest ("solar drying"), which has the advantage of being economical and is usually done within close proximity to the location of harvest. Algae products are also frequently subjected to toasting or hot air drying due to high water activity of the material. More recently, certain algae drying methods have used microwave heating due to purported cost and energy savings, in addition to other methods such as novel infrared drying techniques (Wang, Zhang, and Fang 2019, Uy et al. 2005). Freeze drying can be also used to dehydrate seaweed, but this process can be energy intensive and is likely to be targeted for use on high-value products. Spray drying is generally well-suited to process unicellular algae such as 
Spirulina because this process can drive off the high water content that is inherent in its bulk cultivation. Although drying represents a major processing strategy for commercially produced algae-based foods, not all commercial algae-based foods are dried products. Nori tsukudani is a centuries-old jam or paste-like food made from boiling seaweed (Monostroma spp.) with seasoning, typically soy sauce and sweet rice wine (Mouritsen, Rhatigan, and Pérez-Lloréns 2018). Modern commercialized versions are made shelf-stable via thermal processing and are packaged in glass jars, but use of high pressure processing and cold plasma processing have been more recently applied on algae, which may be related to ongoing research of these methods to process a variety of other food products (Beyrer et al. 2020, del Olmo, Picon, and Nuñez 2020, Bansal et al. 2019, Chakraborty et al. 2017). Although less popular in Western markets, thermally processed algae purees have emerged as niche products. Other food applications include the use of algae to partially substitute ingredients in products such as minced fish and noodles (Debbarma et al. 2017, Dewi 2011).

\section{Overview of nutritional and phytochemicals in algae}

Algae contain an array of macronutrients, micronutrients, and a variety of phytochemicals (Table 1). The potential impacts of algae consumption on human health outcomes have been previously reviewed elsewhere (Brown et al. 2014), so here we focus on the effect of thermal processing on major components—-macronutrients, micronutrients, and phytochemicals—in algae. 
Table 1. Nutrient composition of select algae varieties found in the diet and in food supplements. a,b

\begin{tabular}{|c|c|c|c|c|c|c|c|c|c|}
\hline Nutrient & Unit $^{c}$ & Himanthalia & $\begin{array}{c}\text { Undaria } \\
\text { (wakame) }\end{array}$ & $\begin{array}{c}\text { Porphyra } \\
\text { (nori) }\end{array}$ & $\begin{array}{c}\text { Ulva } \\
\text { (sea } \\
\text { lettuce) }\end{array}$ & $\begin{array}{l}\text { Palmaria } \\
\text { (dulse) }\end{array}$ & $\begin{array}{l}\text { Laminaria } \\
\text { (kelp) }\end{array}$ & Spirulina & Chlorella \\
\hline Vitamin $B_{12}$ & $\mu \mathrm{g} / 100 \mathrm{~g} \mathrm{FW}$ & $\mathrm{N} / \mathrm{A}$ & 0.35 & 0.77 & 6.3 & 1.8 & 0.50 & $60-240^{* *}$ & $0-240^{* *}$ \\
\hline $\begin{array}{l}\text { Vitamin E ( } \alpha- \\
\text { tocopherol) }\end{array}$ & $\mathrm{mg} / 100 \mathrm{~g} \mathrm{FW}$ & 2.2 & 16 & $0.34-1.3$ & ND & $0.17-15$ & 3.1 & $2.8-75$ & $\mathrm{~N} / \mathrm{A}$ \\
\hline Calcium & $\mathrm{mg} / 100 \mathrm{~g} \mathrm{DW}$ & $57-910$ & 930 & $390-690$ & 620 & 280 & $690-1,000$ & $220-1,300$ & 590 \\
\hline Copper & $\mathrm{mg} / 100 \mathrm{~g} \mathrm{DW}$ & 0.19 & $0.38-0.56$ & $0.19-2.9$ & $0.40-0.57$ & 0.76 & $0.2-1.7$ & $0.12-0.49$ & 0.06 \\
\hline Magnesium & $\mathrm{mg} / 100 \mathrm{~g} \mathrm{DW}$ & $170-830$ & $830-1,200$ & $280-570$ & 880 & 190 & $660-770$ & $370-400$ & 340 \\
\hline Manganese & $\mathrm{mg} / 100 \mathrm{~g} D W$ & 4.1 & $0.85-0.87$ & 2.2-2.7 & $N / A$ & $\mathrm{~N} / \mathrm{A}$ & $0.4-3.8$ & $2.6-11$ & 2.1 \\
\hline Potassium & $\mathrm{mg} / 100 \mathrm{~g} \mathrm{DW}$ & $2,600-6,700$ & $8,700-11,000$ & $1,400-3,500$ & 470 & 2200 & $3,800-12,00$ & $1,600-3,100$ & 50 \\
\hline Zinc & $\mathrm{mg} / 100 \mathrm{~g} \mathrm{DW}$ & $3.2-3.8$ & $1.7-6.1$ & $3.7-4.2$ & $1.1-1.7$ & 0.57 & $0.1-5.4$ & $0.5-79$ & 1.2 \\
\hline
\end{tabular}

aData compiled from Careri et al. (2001); Cha et al. (2012); Cofrades et al. (2010); Dey and Rathod (2013); Edelmann et al. (2019); Ferraces-Casais et al. (2012); García-Casal et al. (2007); García-Sartal et al. (2013); Grosshagauer et al. (2020); Kakita and Obika (2017); MacArtain et al. (2007); Ruperez (2002); Schiener et al. (2015); Tokusoglu and Unal (2003).

${ }^{b}$ Abbreviations used: DW, dry weight; FW, fresh weight; N/A, not available; ND, not detected.

'Data not presented as per dry weight in literature source was corrected for moisture content.

${ }^{*}$ Data presented as $\mathrm{mg} / 100 \mathrm{~g} \mathrm{DW}$.

**Data presented as $\mu \mathrm{g} / 100 \mathrm{~g}$ DW. 
Algae are typically composed of greater than $70 \%$ carbohydrates and fibers, which includes components such as cellulose, alginate, carrageenan, sugar alcohols, and glucans. (Schiener et al. 2015, Stiger-Pouvreau, Bourgougnon, and Deslandes 2016). Many of these carbohydrates are used by the food industry to impart certain desired physical properties to foods. Additionally, some of these components have putative bioactive properties, such as sulfated polysaccharides, which reportedly has in vitro anti-viral activity against dengue virus and SARS-CoV-2 (Kwon et al. 2020, Talarico et al. 2005).

The lipid content of algae can range from less than $1 \%$ for kelp, $\sim 10 \%$ for chlorella, and as high as 70\% in certain types of microalgae (Callegari et al. 2020, Schiener et al. 2015, Chi et al. 2019). The fatty acid composition of green algae is composed of both saturated and unsaturated fatty acids, with palmitic acid (C16:0), oleic acid (C18:1), and linolenic acid (C18:3) being the predominant constituents, although the $\mathrm{n}-3$ fatty acid concentrations in select microalgae can position them as a potential alternative to fish oils (Ryckebosch et al. 2014).

Algae can be a significant source of protein, containing both essential and non-essential amino acids. Several red algae varieties contain high amounts of glutamate and aspartate relative to the other amino acids present in the plant, which may be why these foods are often used as flavor enhancers in food preparation (Cofrades et al. 2010). Multiple assays have also been conducted to estimate its protein quality. For instance, studies to determine the protein efficiency ratio (PER) of Chlorella and Spirulina have found that that it is $\sim 2.0$ for these algae, as compared to 2.7 for casein (Kose et al. 2017, Dawczynski, Schubert, and Jahreis 2007, Becker 2007). The protein digestibility-corrected amino acid score (PDCAAS) of red seaweed (Porphyra sp.) has been reported as $\sim 0.43$ compared to 1.0 for casein (Cian et al. 2014). The digestible indispensable amino acid score (DIAAS) is currently the recommended protein quality 
measurement for human nutrition (Leser 2013), but has not been well reported for algae because of a lack of standardized data on ileal digestibility of algal amino acids (Angell et al. 2016). The PER and PDCAAS values of previously reported algae species exclude it from being deemed an excellent quality source of protein. However, algae have been posited as a sustainable source of dietary protein due to its low land usage, relatively high yield, and low energy input, which may make it appropriate for partial protein supplementation in animal feed or formulated human foods (Klamczynska and Mooney 2017, Schwenzfeier, Wierenga, and Gruppen 2011). Because thermal processing has been reported to affect liberation of amino acids from an algae food matrix, it is important to continue to characterize the degree to which processing ultimately affects protein quality in this matrix (Maehre et al. 2016).

Significant amounts of essential minerals and trace metals can be present in algae. Kelp in particular is known to contain high amounts of the trace element I. In the Japanese diet, it is estimated that up to 1-3 mg I per day is obtained from algae such as kelp, and amounts as high as $4.8 \mathrm{mg}$ I per day are consumed by Taiwanese populations from algae sources (Zava and Zava 2011, Domínguez-González et al. 2017). Sea spaghetti (H. elongata), wakame (U. pinnatifida) and nori (P. umbilicalis) all contain 1-10\% dry weight (DW) of the minerals potassium (K), sodium $(\mathrm{Na})$, and calcium $(\mathrm{Ca})$, and $0.3-0.8 \%$ magnesium $(\mathrm{Mg})$. Other notable nutritional elements in algae include iron (Fe), manganese (Mn), zinc ( $\mathrm{Zn}$ ) (Cofrades et al. 2010, Tokuşoglu and Üunal 2003). These levels of minerals in algae are consistent with another report indicating that Fucus, Laminaria, wakame, Chondrus, and nori contain $~ 3-11 \%$ DW Na and K and 0.4-1\% DW Ca and Mg (Rupérez 2002). Additionally, clinical studies assessing the Fe bioavailability from several types of cooked algae have determined it to range from $12-22 \%$, which is higher 
than the Fe bioavailability of 5-12\% typically observed in those consuming vegetarian diets (Masuda, Yamamoto, and Toyohara 2015, García-Casal et al. 2007).

Multiple studies have characterized the amount of both water- and fat-soluble vitamins in algae, such as B vitamin complex, ascorbic acid (vitamin C), pro-vitamin A carotenoids, and tocopherols (vitamin E) (Seshadri, Umesh, and Manoharan 1991, Edelmann et al. 2019, MacArtain et al. 2007). Spirulina and nori in particular have been described as being a potential vegetarian source of vitamin $B_{12}$ because this vitamin can be found in relatively high concentrations in these algae varieties (Croft et al. 2005). Although initial pre-clinical animal studies assessing the bioavailability of $\mathrm{B}_{12}$ from algae appeared to be promising, human studies have produced mixed results and do not appear to support it being bioavailable (Dagnelie, van Staveren, and van den Berg 1991, van den Berg, Brandsen, and Sinkeldam 1991). Nori and Himanthalia contain ascorbic acid at levels ranging from $30-50 \mathrm{mg} / 100 \mathrm{~g}$ fresh weight (FW), but other species (i.e., kombu and dulse) contain only very low amounts ( $<1 \mathrm{mg} / 100 \mathrm{~g} \mathrm{FW}$ ) (Ferraces-Casais et al. 2012). All four types of these algae contain limited amounts of $\alpha$ tocopherol (0.2-2.2 mg/100 $\mathrm{g} \mathrm{FW})$ and pro-vitamin A $\beta$-carotene (2-4 mg/100 g FW). As a comparison, Spirulina can contain $\beta$-carotene at levels approximately 100-fold higher (Seshadri, Umesh, and Manoharan 1991). These results indicate that variability of nutritional components in algae can be significant and that ongoing analytical work is needed to more fully characterize the occurrence of these compounds in algae.

Pigments, particularly carotenoids, have been extracted from various algal species. Some research has focused on carotenoids in the context of pro-vitamin A (Seshadri, Umesh, and Manoharan 1991, Kakita and Obika 2017); however algae are also a source of carotenoids without pro-vitamin A activity (Careri et al. 2001). Unlike other dietary carotenoid sources, such 
as fruits and vegetables, algae are a source of unique carotenoids that are not found in terrestrial plants, including astaxanthin, fucoxanthin, diatoxanthin, and diadinoxanthin (Boussiba and Vonshak 1991, Maeda et al. 2018, Ambarsari et al. 1997). Carotenoid composition varies depending on the type of algae, the type and intensity of light exposure, and environmental stress/nutrient starvation (Ota et al. 2018, Kondzior, Tyniecki, and Butarewicz 2019, He, Duncan, and Barber 2007, Boussiba et al. 1999, Kobayashi et al. 1992). Haematococcus pluvialis, a freshwater green alga, has also been well studied and is used commercially, particularly for its ability to biosynthesize and accumulate high amounts of astaxanthin. The actual amount of astaxanthin in Haematococcus pluvialis depends on growth conditions; thus, much research efforts have gone toward manipulating environmental and nutritional conditions, such as optimizing application of light wavelengths and targeting mineral concentrations necessary for its growth, such as Fe, P, and sulfur (S) (He, Duncan, and Barber 2007). Much of this research indicates that astaxanthin yields are roughly 2-4\% DW of Haematococcus pluvialis (Martínez et al. 2019, Olaizola 2000, Boussiba et al. 1999, Irshad et al. 2019).

Chlorophylls and other non-carotenoid pigments such as phycobiliproteins are found in algae. Chlorophyll exists abundantly in various plants and algae as light harvesting pigments for the photosynthesis process and is used in the food industry as natural food color (Humphrey 2004). Unlike flowering plants, algae do not require exposure to light in order to initiate chlorophyll synthesis (Suzuki and Bauer 1995). When cultured under optimal conditions, Chlorella has been reported to contain $4 \%$ DW chlorophyll (Kong et al. 2014). Phycobiliproteins, found mainly in red algae and cyanobacteria, are high-value pigment proteins that have applications for food, cosmetic, and biomedical industries (Pereira et al. 2020). Phycobiliproteins can be divided into the two main classes, phycoerythrins and phycocyanins, 
and these compounds have been reported in Gracillaria spp. at 0.46-1.3 mg/g and 0.11-0.28 mg/g for phycoerythrin and phycocyanin, respectively (Tello-Ireland et al. 2011, Gómez et al. 2005, Beer and Eshel 1985). As extracted and purified compounds, phycobiliproteins are of interest for their potential bioactive effects, but have also shown functional potential as emulsifiers in food systems (Chen et al. 2017).

Generally speaking, varying pigment yields across studies may be partly due to differences in biosynthesis from algae, but yields are greatly influenced by extraction conditions and quantification methodology. Solvent choice can influence yields by selectively extracting certain polar or nonpolar carotenoids or pigments more efficiently, and certain extraction techniques have been shown to be more effective at physically liberating pigments from algae cells, as also with other food matrices (Simon and Helliwell 1998, Varapasad et al. 2019, Shinwari and Rao 2018b). Indeed, carotenoid profiles from identical algae sample have been shown to be qualitatively different when extracted using pressurized liquid extraction (PLE) compared to a combination of PLE and supercritical antisolvent fractionation (SAF), an isolation and concentration technique, potentially due to differences in carotenoid relative solubility or potential transformation during processing (Gallego et al. 2020). Quantification methodology that relies on spectrophotometry should be interpreted with caution because it can overestimate carotenoid and other pigment concentrations and does not distinguish between different compounds or isomers. For example, presence of chlorophyll degradation products, including chlorophyllide a and phaeophytin a, resulted in at least a $\sim 10 \%$ overestimation of chlorophyll when quantified from algae using spectrophotometry compared to high pressure liquid chromatography (HPLC) (Schagerl and Künzl 2007). 


\section{Effect of thermal processing on vitamin retention in algae}

Ongoing research has characterized how post-harvest processing affects concentrations of select micronutrients in algae-based foods (Table 2). Because several vitamins are in vitro antioxidants, they may be particularly sensitive to oxidative and thermal degradation. Figure 3 displays a simplified schematic of how processing affects the nutritional and phytochemical constituents in algae. Jensen (1969) performed one of the earliest studies on this topic and determined the effect of processing and storage on water- and fat-soluble vitamins in algae. In this study, fresh Norwegian kelp (Ascophyllum nodosum) was harvested, processed by drying at $40^{\circ} \mathrm{C}$, and then subsequently held in a storage silo for up to 16 days. The results showed that although there was $50 \%$ loss of ascorbic acid during storage of the fresh material, the fat-soluble vitamins $\beta$-carotene and $\alpha$-tocopherol were highly retained over this period. Further monitoring of target vitamins during storage indicated that humidity and temperature $\left(4-25^{\circ} \mathrm{C}\right)$ were significant factors that corresponded to decreased levels of these compounds over time. Similarly, retention of ascorbic acid in brown algae (S. hemiphyllum) was found to be affected by the type of drying method, with the data indicating that freeze-dried algae contained up to 3-fold greater amounts of this vitamin compared to samples that were hot air or solar dried (Chan, Cheung, and Ang 1997).

Limited data suggest that in-home processing can affect the levels of ascorbic acid in kombu (Laminaria sp.) and wakame (Undaria pinnatifida) (Amorim, Lage-Yusty, and LópezHernández 2012). Boiling these algae for 20-60 min resulted in significant reductions of ascorbic acid, which is consistent with literature demonstrating that boiling vegetables reduces levels of water-soluble vitamins, such as ascorbic acid (Delchier, Reich, and Renard 2012). 
Table 2. Summary of literature on the effect of processing on vitamin concentrations in algae. ${ }^{a}$

\begin{tabular}{|c|c|c|c|c|c|}
\hline Vitamin & Algae & Processing & $\begin{array}{l}\text { Approximate retention } \\
\text { after processing }\end{array}$ & Analytical Method & Reference \\
\hline Vitamin $A$ ( $\beta$-carotene) & $\begin{array}{l}\text { Ascophyllum } \\
\text { (rockweed) }\end{array}$ & Storage at $4-25^{\circ} \mathrm{C}$ & $30-60 \%$ & Paper chromatography & (Jensen 1969) \\
\hline Vitamin A ( $\beta$-carotene) & Spirulina & Spray dried & $90 \%$ & Column chromatography & $\begin{array}{l}\text { (Seshadri, Umesh, and } \\
\text { Manoharan 1991) }\end{array}$ \\
\hline Vitamin A ( $\beta$-carotene) & Laminaria (kombu) & Dried at $45^{\circ} \mathrm{C}$, then boiled & $200 \%$ & HPLC-VWD & $\begin{array}{l}\text { (Amorim, Lage-Yusty, and } \\
\text { López-Hernández 2012) }\end{array}$ \\
\hline Vitamin A ( $\beta$-carotene) & Undaria (wakame) & Dried at $45^{\circ} \mathrm{C}$, then boiled & $290 \%$ & HPLC-VWD & $\begin{array}{l}\text { (Amorim, Lage-Yusty, and } \\
\text { López-Hernández 2012) }\end{array}$ \\
\hline Vitamin $A$ ( $\beta$-carotene) & Fucus & Hot air dried at $25-60^{\circ} \mathrm{C}$ & No change & HPLC-UV/VIS-MS & (Silva et al. 2019) \\
\hline $\begin{array}{l}\text { Vitamin C (ascorbic } \\
\text { acid) }\end{array}$ & $\begin{array}{l}\text { Ascophyllum } \\
\text { (rockweed) }\end{array}$ & Storage at $4-25^{\circ} \mathrm{C}$ & $50 \%$ & $\begin{array}{c}\text { Titration with 2,6- } \\
\text { dichlorophenol-indophenol }\end{array}$ & (Jensen 1969) \\
\hline $\begin{array}{l}\text { Vitamin } C \text { (ascorbic } \\
\text { acid) }\end{array}$ & $\begin{array}{l}\text { Sargassum (brown } \\
\text { seaweed) }\end{array}$ & $\begin{array}{l}\text { Sun dried, oven dried, or } \\
\text { freeze dried }\end{array}$ & $\begin{array}{c}\text { Freeze dried (no change); } \\
\text { oven dried (70\%); sun dried } \\
(30 \%)\end{array}$ & $\begin{array}{l}\text { 2,4-dinitrophenylhydrazine } \\
\text { method }\end{array}$ & (Chan, Cheung, and Ang 1997) \\
\hline $\begin{array}{l}\text { Vitamin } \mathrm{C} \text { (ascorbic } \\
\text { acid) }\end{array}$ & Undaria (wakame) & Dried at $45^{\circ} \mathrm{C}$, then boiled & $0 \%$ & HPLC-UV/VIS & $\begin{array}{l}\text { (Amorim, Lage-Yusty, and } \\
\text { López-Hernández 2012) }\end{array}$ \\
\hline $\begin{array}{l}\text { Vitamin E ( } \alpha- \\
\text { tocopherol) }\end{array}$ & $\begin{array}{l}\text { Ascophyllum } \\
\text { (rockweed) }\end{array}$ & Storage at $4-25^{\circ} \mathrm{C}$ & $0-50 \%$ & Paper chromatography & (Jensen 1969) \\
\hline $\begin{array}{l}\text { Vitamin } E(\alpha- \\
\text { tocopherol) }\end{array}$ & Undaria (wakame) & Dried at $45^{\circ} \mathrm{C}$, then boiled & No change & HPLC-FL & $\begin{array}{l}\text { (Amorim, Lage-Yusty, and } \\
\text { López-Hernández 2012) }\end{array}$ \\
\hline $\begin{array}{l}\text { Vitamin } E(\alpha- \\
\text { tocopherol) }\end{array}$ & Laminaria (kombu) & Dried at $45^{\circ} \mathrm{C}$, then boiled & No change & HPLC-FL & $\begin{array}{l}\text { (Amorim, Lage-Yusty, and } \\
\text { López-Hernández 2012) }\end{array}$ \\
\hline
\end{tabular}

${ }^{a}$ Abbreviations used: HPLC, high-performance liquid chromatography; MS, mass spectrometer; VWD, variable wavelength detector; UV/VIS, ultra violet/visible detector; FL, fluorescence detector.

${ }^{\mathrm{b}}$ Retention was estimated by calculating [compound concentration after processing]/[compound concentration before processing] ${ }^{\star} 100 \%$. Values greater than $100 \%$ may indicate enhanced extractability from a modified food matrix due to processing. 


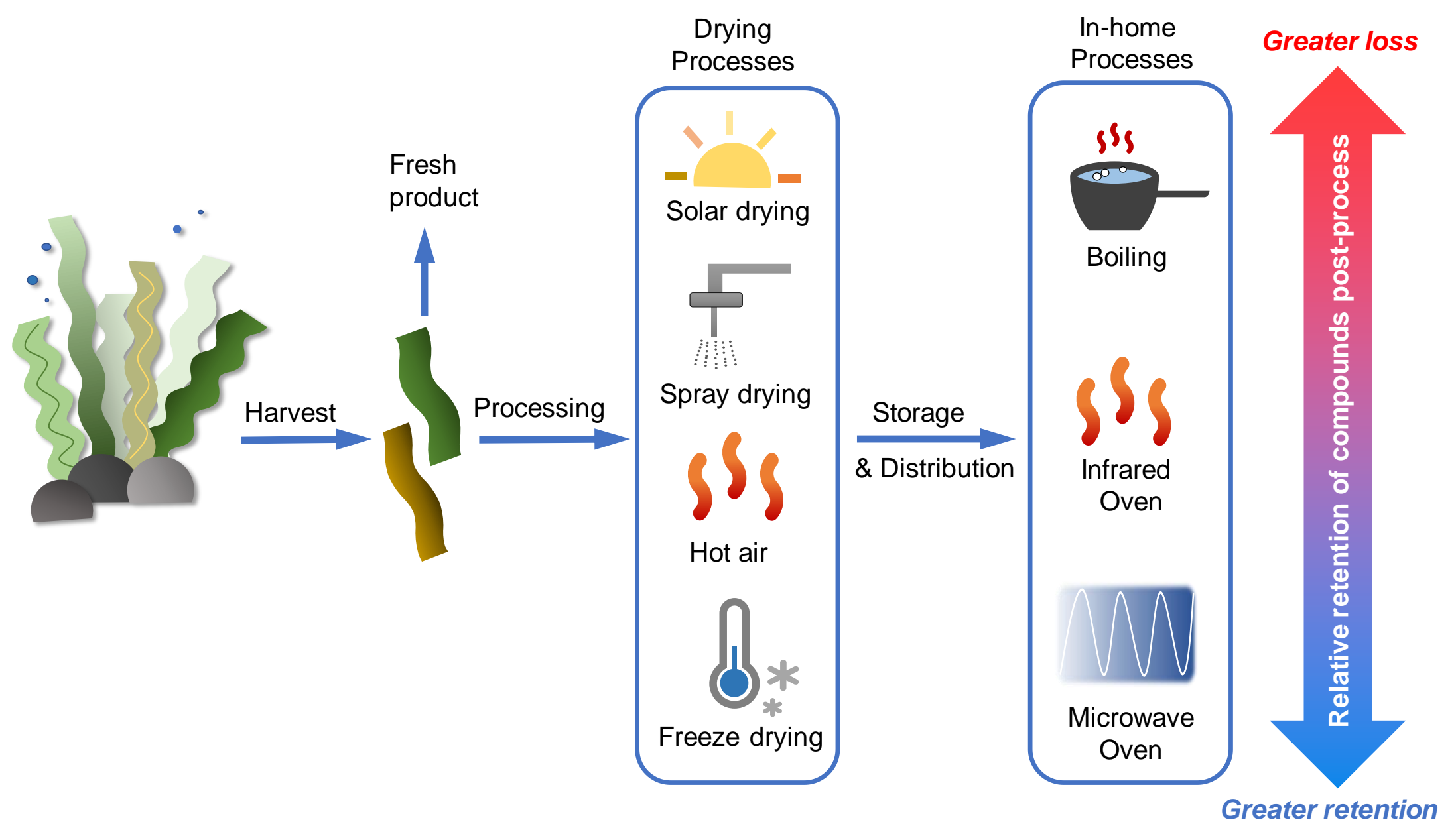

Figure 3. Simplified flowchart of the overall post-harvest processing scheme of algae and the effect on vitamin and phytochemical constituents. After algae is harvested, it can be consumed fresh or subjected to drying processes to prevent spoilage. After the consumer receives the product, it can be consumed as is, or otherwise be further thermally processed before consumption. Processing methods are presented in ascending order of increasing effect on loss of vitamin and phytochemical components. 
Effect of thermal processing on phytochemical retention in algae: Carotenoids, chlorophyll and other pigments, and phenolic compounds

\section{Carotenoids}

Besides the vitamins present in algae, there are multiple phytochemical compounds with putative bioactive effects on human health. Some of these compounds include carotenoids, including pro-vitamin A $\beta$-carotene, lutein, zeaxanthin, and astaxanthin, which are often present in high concentrations (up to 4\% DW) in certain types of algae (Ambati et al. 2018, Terasaki et al. 2012). Carotenoids from algae can be extracted from the plant matrix to produce highly concentrated extracts of $\beta$-carotene that can then be used as a food/dietary supplement ingredient (Dey and Rathod 2013, Poojary et al. 2016). Notably, algae have also been optimized for carotenoid accumulation and are grown commercially as a carotenoid source. In particular, Spirulina and Haemotococcus pluvialis are often used commercially to produce wellcharacterized carotenoid extracts (Park et al. 2018, Hu et al. 2008, Boussiba et al. 1999). However, research on these algae has primarily focused on increasing carotenoid biosynthesis or optimizing extraction yields as opposed to understanding the effect of post-harvest food processing on carotenoid concentrations.

Still, there is ongoing research on how different types of processing methods affect levels of carotenoids and other pigment compounds in algae (Table 3). Seshadri et al. (1991) found that spray drying Spirulina at an inlet temperature of $95-120^{\circ} \mathrm{C}$ reduced $\beta$-carotene concentrations by $\sim 10 \%$, and storage of the dried material in dark-tinted containers over $45 \mathrm{~d}$ resulted in an additional 60\% loss. Similarly, microalgae (Phaeodactylum tricornutum) spray dried at an inlet 
temperature of $180^{\circ} \mathrm{C}$ contained $25 \%$ lower total carotenoids compared to either fresh or freezedried algae (Ryckebosch et al. 2011). However, the spray-dried algae stored over $35 \mathrm{~d}$ at temperatures ranging from $-20^{\circ} \mathrm{C}$ to $20^{\circ} \mathrm{C}$ did not have any additional reduction in total carotenoids. The authors in this study did not perform analysis for individual carotenoids, so it is not possible to determine directly if specific compounds were more susceptible to degradation from the storage conditions. In contrast, a report by Stévant et al. found that fucoxanthin (a xanthophyll) may not be sensitive to certain thermal processing conditions because the authors reported that brown algae (Saccharina latissima) dried at temperatures ranging from $25-70^{\circ} \mathrm{C}$ did not have significantly different levels of fucoxanthin compared to freeze-dried algae (Stévant et al. 2018). Similar results were reported in Fucus, where no difference in fucoxanthin levels were found between sample dried at $60^{\circ} \mathrm{C}$ and control (Silva et al. 2019). Not surprisingly, one study found that subjecting sea lettuce to solar drying resulted in lowest retention of total carotenoids when compared to freeze, vacuum, or hot air drying (Uribe et al. 2019). Together, these results indicate that stability of certain carotenoids in an algae matrix can be affected by thermal processing and subsequent storage, but that these conditions can be optimized in order to achieve greater retention of targeted carotenoid compounds. 
Table 3. Summary of literature on the effect of processing on carotenoids and other pigment compounds in algae. ${ }^{a}$

\begin{tabular}{|c|c|c|c|c|c|}
\hline Compound & Algae & Processing & $\begin{array}{l}\text { Approximate retention } \\
\text { after processing }^{\mathrm{b}}\end{array}$ & $\begin{array}{l}\text { Analytical } \\
\text { Method }\end{array}$ & Reference \\
\hline Carotenoids, total & $\begin{array}{l}\text { Phaeodactylum } \\
\text { tricornutum }\end{array}$ & Spray dried or freeze dried & $\begin{array}{l}\text { Spray dried (75\%); freeze } \\
\text { dried (no change) }\end{array}$ & Spectrophotometry & (Ryckebosch et al. 2011) \\
\hline Carotenoids, total & Pyropia orbicularis & Vacuum dried at $40-80^{\circ} \mathrm{C}$ & $4-60 \%$ & Spectrophotometry & (Uribe et al. 2018) \\
\hline Carotenoids, total & Spirulina & $\begin{array}{l}\text { Cold atmospheric pressure } \\
\text { plasma, } 7-15 \mathrm{~mW} / \mathrm{cm}^{2}\end{array}$ & $65-85 \%$ & Spectrophotometry & (Beyrer et al. 2020) \\
\hline Carotenoids, total & Ulva (sea lettuce) & $\begin{array}{l}\text { Freeze dried (control), hot air } \\
\text { dried at } 70^{\circ} \mathrm{C} \text {, solar dried, or } \\
\text { vacuum dried at } 70^{\circ} \mathrm{C}\end{array}$ & $\begin{array}{l}\text { Hot air dried }(70 \%) \text {, vacuum } \\
\text { dried }(60 \%) \text {; solar dried }(50 \%)\end{array}$ & Spectrophotometry & (Uribe et al. 2019) \\
\hline Chlorophyll pigments (a/b) & Ulva (sea lettuce) & $\begin{array}{l}\text { Freeze dried (control), hot air } \\
\text { dried at } 70^{\circ} \mathrm{C} \text {, solar dried, or } \\
\text { vacuum dried at } 70^{\circ} \mathrm{C}\end{array}$ & $\begin{array}{l}\text { Hot air dried }(25-65 \%) \text {; solar } \\
\text { dried }(30-60 \%) \text {, vacuum dried } \\
(20-70 \%)\end{array}$ & Spectrophotometry & (Uribe et al. 2019) \\
\hline $\begin{array}{l}\text { Chlorophyll pigments } \\
\text { (chlorophyll + pheophytins } \\
\text { + pheophoribides) }\end{array}$ & Ulva (sea lettuce) & $\begin{array}{l}\text { Boiled or microwaved at } \\
800 \mathrm{~W}\end{array}$ & $70-85 \%$ & HPLC-UV/VIS & (Chen and Roca 2018) \\
\hline $\begin{array}{l}\text { Chlorophyll pigments } \\
\text { (chlorophyll + pheophytins } \\
\text { + pheophoribides) }\end{array}$ & Laminaria (kombu) & $\begin{array}{l}\text { Boiled or microwaved at } \\
800 \mathrm{~W}\end{array}$ & $65-75 \%$ & HPLC-UV/VIS & (Chen and Roca 2018) \\
\hline $\begin{array}{l}\text { Chlorophyll pigments } \\
\text { (chlorophyll + pheophytins } \\
\text { + pheophoribides) }\end{array}$ & Porphyra (nori) & $\begin{array}{l}\text { Boiled or microwaved at } \\
\qquad 800 \mathrm{~W}\end{array}$ & $80-90 \%$ & HPLC-UV/VIS & (Chen and Roca 2018) \\
\hline Chlorophyll a & Laminaria (kombu) & Air dried at $45^{\circ} \mathrm{C}$, then boiled & $0 \%$ & HPLC-VWD & $\begin{array}{l}\text { (Amorim, Lage-Yusty, and } \\
\text { López-Hernández 2012) }\end{array}$ \\
\hline Chlorophyll a & Undaria (wakame) & Air dried at $45^{\circ} \mathrm{C}$, then boiled & $0 \%$ & HPLC-VWD & $\begin{array}{l}\text { (Amorim, Lage-Yusty, and } \\
\text { López-Hernández 2012) }\end{array}$ \\
\hline Chlorophyll a & Spirulina & $\begin{array}{l}\text { Cold atmospheric pressure } \\
\text { plasma, } 7-15 \mathrm{~mW} / \mathrm{cm}^{2}\end{array}$ & $40-100 \%$ & Spectrophotometry & (Beyrer et al. 2020) \\
\hline Fucoxanthin & Laminaria (kombu) & Air dried at $45^{\circ} \mathrm{C}$, then boiled & $120 \%$ & HPLC-VWD & $\begin{array}{l}\text { (Amorim, Lage-Yusty, and } \\
\text { López-Hernández 2012) }\end{array}$ \\
\hline Fucoxanthin & Undaria (wakame) & Air dried at $45^{\circ} \mathrm{C}$, then boiled & $150 \%$ & HPLC-VWD & $\begin{array}{l}\text { (Amorim, Lage-Yusty, and } \\
\text { López-Hernández 2012) }\end{array}$ \\
\hline Fucoxanthin & Saccharina (kelp) & Air dried at $25-70^{\circ} \mathrm{C}$ & No change & HPLC-UV/VIS & (Stévant et al. 2018) \\
\hline
\end{tabular}




\begin{tabular}{|c|c|c|c|c|c|}
\hline Fucoxanthin & Fucus & Air dried at $25-60^{\circ} \mathrm{C}$ & $\begin{array}{l}200 \% \text { at } 40^{\circ} \mathrm{C} \text {; no change for } \\
\text { other treatments }\end{array}$ & HPLC-UV/VIS-MS & (Silva et al. 2019) \\
\hline Lutein & Undaria (wakame) & Air dried at $45^{\circ} \mathrm{C}$, then boiled & 13-fold increase & HPLC-VWD & $\begin{array}{l}\text { (Amorim, Lage-Yusty, and } \\
\text { López-Hernández 2012) }\end{array}$ \\
\hline Lutein & Fucus & Air dried at $25-60^{\circ} \mathrm{C}$ & No change & HPLC-UV/VIS-MS & (Silva et al. 2019) \\
\hline Lutein & Ulva (sea lettuce) & Air dried at $25-60^{\circ} \mathrm{C}$ & $\begin{array}{l}3 \text {-fold increase at } 25^{\circ} \mathrm{C} \text {; no } \\
\text { change for other treatments }\end{array}$ & HPLC-UV/VIS-MS & (Silva et al. 2019) \\
\hline Pheophytin a & Laminaria (kombu) & Air dried at $45^{\circ} \mathrm{C}$, then boiled & 24-fold increase & HPLC-VWD & $\begin{array}{l}\text { (Amorim, Lage-Yusty, and } \\
\text { López-Hernández 2012) }\end{array}$ \\
\hline Pheophytin a & Undaria (wakame) & Air dried at $45^{\circ} \mathrm{C}$, then boiled & 30-fold increase & HPLC-VWD & $\begin{array}{l}\text { (Amorim, Lage-Yusty, and } \\
\text { López-Hernández 2012) }\end{array}$ \\
\hline Phycocyanin & Gracilaria chilensis & Air dried at $40-70^{\circ} \mathrm{C}$ & $\begin{array}{c}\text { 2-3-fold increase at } 40-50^{\circ} \mathrm{C} ; \\
\text { no change for other } \\
\text { treatments }\end{array}$ & Spectrophotometry & (Tello-Ireland et al. 2011) \\
\hline Phycocyanin & Pyropia orbicularis & Vacuum dried at $40-80^{\circ} \mathrm{C}$ & $110-170 \%$ & Spectrophotometry & (Uribe et al. 2018) \\
\hline Phycocyanin & Spirulina & $\begin{array}{c}\text { Cross flow dried }\left(60^{\circ} \mathrm{C}\right), \\
\text { spray dried }\left(150^{\circ} \mathrm{C}\right) \text {, or oven } \\
\text { dried }\left(60^{\circ} \mathrm{C}\right)\end{array}$ & $50 \%$ & Spectrophotometry & $\begin{array}{c}\text { (Sarada, Pillai, and Ravishanka } \\
\text { 1999) }\end{array}$ \\
\hline Phycocyanin & Spirulina & $\begin{array}{l}\text { Cold atmospheric pressure } \\
\text { plasma, } 7-15 \mathrm{~mW} / \mathrm{cm}^{2}\end{array}$ & $40-100 \%$ & Spectrophotometry & (Beyrer et al. 2020) \\
\hline
\end{tabular}

a Abbreviations used: HPLC, high-performance liquid chromatography; VWD, variable wavelength detector; UV/VIS, ultra violet-visible detector.

${ }^{b}$ Retention was estimated by calculating [compound concentration after processing]/[compound concentration before processing] ${ }^{*} 100 \%$. Values greater than $100 \%$ may indicate enhanced extractability from a modified food matrix due to processing. 
Although preliminary, some limited data suggest that in-home processing can increase levels of certain carotenoids in algae. For instance, levels of $\beta$-carotene, fucoxanthin, and lutein have reportedly increased after boiling kombu (Laminaria sp.) and wakame (Undaria pinnatifida) (Amorim, Lage-Yusty, and López-Hernández 2012). It is possible that these increases may be the result of conversion/degradation of other compounds to carotenoids, but the authors note that this increase may be related to increased extractability of the compounds and not true increases, because compound recovery could not be adequately tested. Thus, it is difficult to ascertain in this context whether increases in carotenoids were in fact directly due to the cooking process.

Aside from the effects of processing on carotenoid content, processing may potentially be leveraged to increase the bioaccessibility or bioavailability of carotenoids in algae for human consumption. One study that used microfluidization to dramatically decrease particle size of Chlorella sp. from $\sim 2,463 \mathrm{~nm}$ to $361 \mathrm{~nm}$ in diameter found significant increases in in vitro bioaccessibility of zeaxanthin and $\beta$-carotene compared to fresh samples (Cha et al. 2012). Additionally, chemical structure of carotenoids is known to potentially influence bioaccessibility and bioavailability, but specific isomer structure is not always investigated in bioavailability studies. Although not studied specifically for algae, other carotenoid-rich foods have been shown to have differences in bioavailability depending on carotenoid isomer form. Indeed, cis-lycopene is more bioavailable compared to all-trans-lycopene in tomato products (Unlu et al. 2007), and the $3 S, 3$ ' $S$-astaxanthin isomer appears to exhibit greater bioavailability compared its other isomers (Rüfer et al. 2008). Because thermal processing can drive isomerization of these compounds (Unlu et al. 2007), further research on how processing affects the carotenoids in algae should be pursued. 


\section{Chlorophyll and other pigment compounds}

Research on pigments such as chlorophyll has been the topic of ongoing work not only due to the bioactive nature of these compounds, but also because degradation of these pigments can result in color changes that may be viewed as less appealing to the consumer. In one study, nori (Porphyra umbilicales), kombu (Laminaria ochroleuca) and sea lettuce (Ulva sp.) were thermally processed by microwave cooking for $15 \mathrm{~min}(800 \mathrm{~W})$ or boiling in water for $20 \mathrm{~min}$ (Chen and Roca 2018). These samples were then analyzed for chlorophylls, chlorophyll degradation products, and pheophytins, which are compounds that can form via heat-catalyzed transformation. Both cooking methods resulted in up to $\sim 35 \%$ loss of total chlorophyll pigments, with the microwaved algae generally having greater retention compared to boiling. Although a large percentage $(\sim 70-80 \%)$ of chlorophyll loss from boiling could be attributed to increases in degradation and conversion products, amounts that could not be accounted for may be due to these compounds portioning into the cooking water. However, due to the authors not reporting analysis of the cooking water, it is difficult to definitely conclude if release of these pigments into the water was the underlying reason for the inability to achieve mass balance.

In another study, processing Spirulina using oven drying/cross-flow drying at $60^{\circ} \mathrm{C}$ or spray drying at $150^{\circ} \mathrm{C}$ resulted in a $\sim 50 \%$ decrease of phycocyanin under both conditions (Sarada, Pillai, and Ravishankar 1999). Follow-up experiments on isolated phycocyanin found that the pigment began to degrade at temperatures above $30^{\circ} \mathrm{C}$, which is consistent with the author's data on pigment stability in the algae matrix. Another study investigated the effects of convective hot air drying on the pigments phycoerythrin and phycocyanin from red algae 
(Gracillaria chilensis) (Tello-Ireland et al. 2011). The results suggest that there may be an optimal drying temperature resulting in maximum pigment retention because pigment retention exhibited a non-linear relationship with temperature, with the peak value at $50^{\circ} \mathrm{C}$ containing $\sim 30$ $50 \%$ higher phycobiliproteins compared to fresh samples. However, it is unclear whether this increase was due to pigment conversion or other factors such as improved extraction.

Because potential for the use of novel technologies to process algae products has been increasing, some studies have considered its impact on important pigment compounds. In one instance, Spirulina powder subjected to processing by cold atmospheric pressure plasma to inactivate pathogens had up to $60 \%$ reduction in chlorophyll a (Beyrer et al. 2020). Results such as these indicate the importance of novel technologies to process algae, but more direct comparisons of novel and legacy methods should be more directly compared in order to help inform the value of these technologies on retention of pigment compounds while reducing pathogenic organisms.

Although there are few studies on the topic, the type of processing may differentially impact the bioavailability of chlorophyll compounds from algae. In one study, authors Chen and Roca (2019) used an in vitro model to show that total chlorophylls from nori, kombu, and sea lettuce exhibited increased bioaccessibility in microwaved compared to boiled algae. Because thermal processing has been demonstrated to alter bioaccessibility of chlorophylls (Ferruzzi, Failla, and Schwartz 2001), it is critical to fully assess the impact of processing on these compounds in algae and to determine the mechanisms driving these observed phenomena. 


\section{Phenolic Compounds}

Phenolic compounds are a class of phytochemicals with one or more phenolic functional groups, and numerous studies have associated consumption of these compounds with various markers of health status in humans (Redan et al. 2016). Because characterization of individual phenolic compounds in algae is ongoing, studies on how processing affects phenolic compounds in algae have generally used non-specific assays that determine total rather than individual concentrations of these compounds (Charles, Sridhar, and Alamsjah 2020, Badmus, Taggart, and Boyd 2019, Ling et al. 2015). The Folin-Ciocalteu method and other nonspecific assays are commonly used to estimate total phenolic compounds in foods and extracts, but they do not provide the selectivity and specificity needed to differentiate phenolic compounds of different classes (Ho et al. 2018). Total phenolic compounds in fresh algae determined using FolinCiocalteu's reagent has ranged from a low of less than $1 \mathrm{mg}$ gallic acid equivalents (GAE) per $100 \mathrm{~g}$ dulse up to $230 \mathrm{mg} / 100 \mathrm{~g}$ GAE for algae in genus Himanthalia (Ferraces-Casais et al. 2012, Jacobsen et al. 2019). Some studies have identified phenolic compounds that appear to be unique to algae, such as eckol and phlorotannins, which are both found in brown algae (Tanna and Mishra 2018), and others have tentatively identified phenolic compounds in algae that are also found in terrestrial plants, such as the flavonoids catechin, epicatechin, epigallocatechin, and quercetin glycosides (Santoso, Yoshie, and Suzuki 2004). Many of these phenolic compounds are in vitro antioxidants so they, similar to antioxidant vitamins, are often sensitive to factors such as temperature and oxygen (Oliveira et al. 2011, Malec et al. 2014, Jiménez-Escrig et al. 2001). As such, the influence of drying methods on phenolic compounds and other phytochemicals in algae has been studied by multiple authors (Table 4). 
Table 4. Summary of literature on the effect of processing on total phenolic compounds in algae. ${ }^{a}$

\begin{tabular}{|c|c|c|c|}
\hline Algae & Processing & $\begin{array}{l}\text { Approximate retention after } \\
\text { processing }^{\mathrm{b}}\end{array}$ & Reference \\
\hline Fucus & Air dried at $50^{\circ} \mathrm{C}$ & $2 \%$ & (Jimenez-Escrig et al. 2001) \\
\hline Fucus & Air dried at $25-60^{\circ} \mathrm{C}$ & $60-70 \%$ & (Silva et al. 2019) \\
\hline Fucus spp. & $\begin{array}{l}\text { Freeze dried (control), oven dried at } 40- \\
60^{\circ} \mathrm{C} \text {, or microwaved dried at 385-700W }\end{array}$ & $5-50 \%$ & $\begin{array}{c}\text { (Badmus, Taggart and Kenneth G. } \\
\text { Boyd 2019) }\end{array}$ \\
\hline Gracilaria & Air dried at $25-60^{\circ} \mathrm{C}$ & No change & (Silva et al. 2019) \\
\hline Halidrys & $\begin{array}{l}\text { Freeze dried (control), oven dried at } 40- \\
60^{\circ} \mathrm{C} \text {, or microwaved dried at 385-700W }\end{array}$ & $\begin{array}{l}\text { Oven dried (40-50\%); microwave cooking } \\
\text { (no change) }\end{array}$ & $\begin{array}{c}\text { (Badmus, Taggart and Kenneth G. } \\
\text { Boyd 2019) }\end{array}$ \\
\hline Himanthalia elongate & Autoclaved at $85-121^{\circ} \mathrm{C}$ & $\begin{array}{c}130-160 \% \text { at } 85-95^{\circ} \mathrm{C} ; 40-100 \% \text { at } 100- \\
121^{\circ} \mathrm{C}\end{array}$ & (Rajauria et al. 2010) \\
\hline Himanthalia elongata & $\begin{array}{l}\text { Boiled, steamed, or microwaved at 450- } \\
\text { 900W }\end{array}$ & $\begin{array}{l}\text { Boiling }(15 \%) \text {; steaming }(70 \%) \text { microwave } \\
\text { cooking }(115-130 \%)\end{array}$ & $\begin{array}{c}\text { (Cox, Abu-Ghannam, and Gupta } \\
\text { 2012) }\end{array}$ \\
\hline Himanthalia elongata & Oven dried at $25-40^{\circ} \mathrm{C}$ & $50-70 \%$ & (Gupta, Cox, Abu-Ghannam 2011) \\
\hline $\begin{array}{c}\text { Kappaphycus alvarezii (elkhorn sea } \\
\text { moss) }\end{array}$ & $\begin{array}{l}\text { Freeze dried (control), solar dried, oven } \\
\text { dried at } 60^{\circ} \mathrm{C} \text {, or vacuum dried at } 60^{\circ} \mathrm{C}\end{array}$ & $\begin{array}{l}\text { solar dried (90\%); oven dried (120\%); } \\
\text { vacuum dried (130\%) }\end{array}$ & (Neoh, Matanjun, and Lee 2016) \\
\hline Laminaria spp. & Autoclaved at $85-121^{\circ} \mathrm{C}$ & $\begin{array}{c}25-100 \% \text { at } 100-121^{\circ} \mathrm{C} ; 140-190 \% \text { at } \\
85-95^{\circ} \mathrm{C}\end{array}$ & (Rajauria et al. 2010) \\
\hline Laminaria (kombu) & Dried at $45^{\circ} \mathrm{C}$, then boiled & $120 \%$ & $\begin{array}{c}\text { (Amorim, Lage-Yusty, and López- } \\
\text { Hernández 2012) }\end{array}$ \\
\hline
\end{tabular}




\begin{tabular}{|c|c|c|c|}
\hline Laminaria (kombu) & $\begin{array}{l}\text { Freeze dried (control), oven dried } 40-60^{\circ} \mathrm{C} \text {, } \\
\text { or microwaved dried at } 385-700 \mathrm{~W}\end{array}$ & No change & $\begin{array}{c}\text { (Badmus, Taggart and Kenneth G. } \\
\text { Boyd 2019) }\end{array}$ \\
\hline Pelvetia (brown algae) & $\begin{array}{l}\text { Freeze dried (control), oven dried } 40-60^{\circ} \mathrm{C} \text {, } \\
\text { or microwaved dried at } 385-700 \mathrm{~W}\end{array}$ & $5-10 \%$; no change for oven dried at $40^{\circ} \mathrm{C}$ & $\begin{array}{c}\text { (Badmus, Taggart and Kenneth G. } \\
\text { Boyd 2019) }\end{array}$ \\
\hline Pyropia & Oven dried at $50^{\circ} \mathrm{C}$ & $70 \%$ & (Jimenez-Escrig et al. 2001) \\
\hline Pyropia orbicularis & Vacuum dried at $40-80^{\circ} \mathrm{C}$ & $90-110 \%$ & (Uribe et al. 2018) \\
\hline Spirulina & Oven dried at $40^{\circ} \mathrm{C}$ & $25 \%$ & (Agustini et al. 2015) \\
\hline Spirulina & $\begin{array}{l}\text { Cold atmospheric pressure plasma, 9- } \\
\qquad 14 \mathrm{~mW} / \mathrm{cm}^{2}\end{array}$ & $90-200 \%$ & (Beyrer et al. 2020) \\
\hline Ulva (sea lettuce) & Air dried at $25-60^{\circ} \mathrm{C}$ & No change & (Silva et al. 2019) \\
\hline Ulva (sea lettuce) & $\begin{array}{l}\text { Freeze dried (control), hot air dried at } \\
70^{\circ} \mathrm{C} \text {, solar dried, or vacuum dried at } 70^{\circ} \mathrm{C}\end{array}$ & $\begin{array}{l}\text { Hot air dried ( } 70 \%) \text {; solar dried (110\%), } \\
\text { vacuum dried (no change) }\end{array}$ & (Uribe et al. 2019) \\
\hline Undaria (wakame) & Air dried at $45^{\circ} \mathrm{C}$, then boiled & $65 \%$ & $\begin{array}{c}\text { (Amorim, Lage-Yusty, and López- } \\
\text { Hernández 2012) }\end{array}$ \\
\hline
\end{tabular}

a'Total phenolic compounds were determined using Folin-Ciocalteu's reagent.

${ }^{b}$ Retention was estimated by calculating [compound concentration after processing]/[compound concentration before processing] ${ }^{\star} 100 \%$. Values greater than $100 \%$ may indicate enhanced extractability from a modified food matrix due to processing. 
In a study by Rajauria et al. (2010), the brown seaweeds Laminaria spp. and Himanthalia elongate were subjected to thermal processing and then analyzed for retention of phenolic compounds. After seaweed samples were autoclaved in a water bath at temperatures ranging from $85-121^{\circ} \mathrm{C}$, the authors found that - similar to pigment retention in algae-levels of total phenolic compounds exhibited a parabolic relationship with temperature, with an optimum at $95^{\circ} \mathrm{C}$. In a study on brown algae (Himanthalia elongata), Gupta et al. found that total phenolic compounds decreased by approximately $30-50 \%$ when algae samples were dried at temperatures ranging from $25-40^{\circ} \mathrm{C}$ for $24 \mathrm{~h}$ (Gupta, Cox, and Abu-Ghannam 2011). In contrast, another author reported no significant differences in total phenolic compounds when green or red algae were hot air dried at temperatures ranging from $25-60^{\circ} \mathrm{C}$ (Silva et al. 2019). Novel technologies such as cold atmospheric pressure plasma have been explored as a processing method to reduce pathogens while increasing retention of phenolic compounds. In one study, the authors found no reduction in phenolic compounds in processed Spirulina powder and actually found increases relative to control in the algae treated at $10-14 \mathrm{~mW} / \mathrm{cm}^{2}$ (Beyrer et al. 2020). The reasons for the increase in total phenolic compounds are unclear, but the authors hypothesize that the processing may have resulted in increased extraction efficacy of these compounds.

López-Hortas et al. $(2018,2019)$ in two different studies evaluated how microwave drying affects levels of phenolic compounds in brown algae (Laminaria ochroleuca and Undaria pinnatifida). Again, the authors found that there was an optimum level of energy application that resulted in greatest retention of phenolic compounds, with the optimum energy application at $300-500 \mathrm{~W}$ under the experimental range of 50-800W. In a study that tested the effect of thermal processing on phenolic compounds in brown algae (Himanthalia elongata), phenolic compounds were determined in samples after boiling, steaming, or microwave cooking (Cox, Abu-Ghannam, 
and Gupta 2012). Microwave cooking resulted in a slight increase in total phenolic compounds, in contrast to steaming and boiling, which resulted in a decrease of $\sim 30 \%$ and $>70 \%$, respectively. It is unknown whether the boiling treatment degraded the phenolic compounds because the cooking water was not analyzed to determine mass balance of these compounds.

Red algae from Malaysia were subjected to different drying treatments where samples were either freeze dried, oven dried, sun dried, or vacuum dried and then analyzed for total phenolic compounds (Neoh, Matanjun, and Lee 2016). Retention of total phenolic compounds were highest in vacuum-dried samples and lowest in samples that were sun dried. In another study on red algae (Pyropia orbicularis), changes in phenolic compounds with vacuum drying red seaweed were documented (Uribe et al. 2018). Similar to other studies, the results of this study indicated that total phenolic compounds increased slightly ( $\sim 10 \%$ compared to control) at the experimental temperatures of $40-80^{\circ} \mathrm{C}$. In a study involving Spirulina, the authors determined that total phenolic compounds decreased by $\sim 75 \%$ after drying sample at $40^{\circ} \mathrm{C}$ for 10 h (Agustini et al. 2015).

Limited data suggest that in-home processing can affect the levels of phenolic compounds in algae. In one study, phenolic compounds decreased in wakame (Undaria pinnatifida) but not in kombu (Laminaria sp.) after being cooked in boiling water (Amorim, Lage-Yusty, and López-Hernández 2012). These results are generally in agreement with other studies finding that boiling and blanching can drive loss of phenolic compounds and nutrients in plant materials (Redan, Vinson, and Coco 2013). Although not specifically tested in these studies on algae, research on other plant materials has demonstrated that loss of phenolic compounds during boiling can largely be attributed to these components partitioning to the water fraction (Wachtel-Galor, Wong, and Benzie 2008). 
Processing temperatures (and times) should be optimized to ensure retention of phenolic compounds from algae. Generally, thermal processing may allow for enhanced release (i.e., enhanced extractability) of phenolic compounds up to a point, but excessive thermal processing can lead to degradation. However, there is some difficulty in determining the factors that are driving the observed parabolic relationship between certain thermal treatments and levels of phenolic compounds in algae. One explanation is that thermal treatment is able to denature endogenous enzymes that oxidize phenolic compounds, such as polyphenol oxidase and peroxidases, resulting in higher retention of these compounds at temperatures where these enzymes are denatured (Ludikhuyze et al. 2003). Use of blanching and other heat treatments to deactivate such enzymes has been well-characterized in many other foods, and such treatments for use on algae are likely to have similar outcomes (Rawson et al. 2011, Shinwari and Rao 2018a). Another possibility is that drying the freshly harvested material induces an adaptive stress response by the plant, which in turn increases levels of phenolic compounds. Alternatively, it is also likely that the observed increases may be due to release of free reducing sugars during the thermal treatment, which can then act as analytical interferences to inflate the values of such nonspecific assays. Follow-up analysis of individual compounds and additional mechanistic experiments are needed in further determining the effect of thermal processing on such compounds in the algae matrix.

It is important to note that many of the aforementioned studies only performed analysis of the compounds in the material and did not consider the in vivo bioavailability of these components. The bioavailability and downstream potential biological effects of these phytochemicals are important because some compounds derived from algae have been reported to have low oral bioavailability, which could ultimately affect potential bioactivity (Asai, 
Yonekura, and Nagao 2008). Additionally, the process of digestion is critical to fully understanding bioavailability of these compounds because the $\mathrm{pH}$ environment may affect compound stability of these phytochemicals (Guo et al. 2019). Further, some research has indicated that high-molecular weight molecules in algae such as phlorotannins can be catabolized by gut microbiota to yield compounds with increased bioavailability (Corona et al. 2017).

Effect of thermal processing on concentrations of elemental and trace metal components in algae

\section{Minerals and trace metals}

Algae can be a significant source of nutritionally relevant elements, including macro- and trace minerals. Due to the high amounts of the trace mineral I in several types of algae, there are multiple studies that have determined how processing affects concentrations of I and other elements in algae (Table 5). In one study, the authors found that levels of I in kelp decreased by $90 \%$ after being boiled for 20 min (Chung et al. 2013). Subsequent analysis of the cooking water showed that virtually all I lost from the kelp had been released into the water. Furthermore, a systematic study determined how different steps of postharvest processing affects I concentrations from the three main classes of algae (red, green, and brown) (Nitschke and Stengel 2016). The authors performed analysis for I after freshly harvesting the material, washing, drying over $72 \mathrm{~h}$, rehydrating over $24 \mathrm{~h}$, and then finally boiling for $20 \mathrm{~min}$. The results revealed that I concentrations were minimally affected after washing and drying, but that rehydration and cooking reduced I concentration by up to $75 \%$. In a study focusing on the trace 
minerals $\mathrm{Cu}, \mathrm{Fe}, \mathrm{Se}$, and $\mathrm{Zn}$, the authors determined how boiling affected the concentrations of nutritional elements in different types of algae (García-Sartal et al. 2013). In this study, the authors found that cooking kombu, wakame, nori, and sea lettuce in boiling water for up to 60 min decreased $\mathrm{Cu}, \mathrm{Fe}, \mathrm{Zn}$, and Se levels by amounts ranging from 50-90\%, 20-80\%, 0-35\%, and 20-60\%, respectively. Combined, these results show a clear trend across studies that indicate processing algae by soaking and boiling results in loss of nutritionally relevant minerals.

\section{Heavy metals}

Several metal contaminants have been reported to occur in algae at varying levels, including the toxic heavy metals $\mathrm{As}, \mathrm{Cd}, \mathrm{Pb}$, and $\mathrm{Hg}$, with As receiving much of the research attention (Luvonga et al. 2020, Almela et al. 2002). The element As naturally occurs as both organic and inorganic species (iAs), with exposure to the inorganic forms (As ${ }^{\mathrm{III}}$ and $\mathrm{As} \mathrm{s}^{\mathrm{V}}$ ) having the strongest association with toxic endpoints and chronic disease, including different types of cancer (CONTAM 2009). The As species in various types of algae have been characterized and has shown that As generally occurs in these foods as the organic forms of arsenosugars and methylated species (Taylor and Jackson 2016, Li et al. 2017). Organic forms of As have been researched in several animal and human clinical studies, and they have been found to be rapidly excreted, with low potential for toxicity (Taylor and Jackson 2016, Taylor, Goodale, et al. 2017, Taylor, Li, et al. 2017). Due to the different levels of toxicity associated with inorganic versus organic forms, it is critical that analytical methods used in surveys of As in algae products differentiate between chemical As species. Accordingly, governmental agencies such as the US Food and Drug Administration (FDA) have ongoing work on the development and evaluation of 
methods used for speciation of As in seaweed and seafood products (Wolle and Conklin 2018, Redan and Jackson 2020).

An analysis of wakame, nori, and kombu found that they all contained non-detectable levels of iAs, but concentrations of arsenosugars ranged from 18-46 mg/kg. In contrast, hijiki can be a concern from the viewpoint of food safety because it has been reported to contain levels as high as $120 \mathrm{mg} / \mathrm{kg}$ iAs ( 120 ppm) (Food Standards Australia New Zealand 2016). In addition, in vitro bioaccessibility of iAs from hijiki has been found to be relatively high, reaching approximately 80\% (Brandon, Janssen, and de Wit-Bos 2014). To place these values in perspective, Food Standards Australia New Zealand (FSANZ) set a maximum limit of $1 \mathrm{mg} / \mathrm{kg}$ iAs for seaweed, which aligns with the Food Chemicals Codex (FCC) recommended limit of 1 $\mathrm{mg} / \mathrm{kg}$ total As for kelp used as a food ingredient (FCC 2016, FSANZ 2016). The FCC indicates that the purpose for this limit is related to use of kelp as an I source in dietary supplements, but this limit may not have been intended for algae consumed in larger amounts. Although there are currently no other regulatory limits specifically related to algae products intended for human consumption, it is interesting to note Health Canada's limit of $0.1 \mathrm{mg} / \mathrm{kg}$ total As for ready-todrink beverages and the FDA proposed limit of $0.1 \mathrm{mg} / \mathrm{kg}$ and $0.01 \mathrm{mg} / \mathrm{kg}$ iAs for rice and apple juice, respectively (Health Canada 2017, FDA 2018). Because levels of iAs in hijiki have at times exceeded the FCC's recommended limit, multiple health communication warnings by governmental bodies have advised caution when consuming this algae (FSANZ 2016, Canadian Food Inspection Agency 2019). 
Table 5. Summary of literature on the effect of processing on minerals and trace elements in algae. ${ }^{a}$

\begin{tabular}{|c|c|c|c|c|c|}
\hline Element & Algae & Processing & $\begin{array}{l}\text { Approximate } \\
\text { retention after } \\
\text { processing }^{\mathrm{b}}\end{array}$ & Analytical Method & Reference \\
\hline Arsenic, inorganic & Hizikia fusiforme (hijiki) & $\begin{array}{c}\text { Soaked in water, then } \\
\text { boiled }\end{array}$ & $10 \%$ & LC-ICP-MS & (Ichikawa et al. 2006) \\
\hline Arsenic, total & Porphyra (nori) & Boiled & No change & ICP-MS & $\begin{array}{c}\text { (Cheyns, Waegeneers, Wiele, } \\
\text { and Ruttens 2017) }\end{array}$ \\
\hline Arsenic, inorganic & Hizikia fusiforme (hijiki) & $\begin{array}{c}\text { Soaked in water, then } \\
\text { boiled }\end{array}$ & $60 \%$ & LC-ICP-MS & $\begin{array}{c}\text { (Cheyns, Waegeneers, Wiele, } \\
\text { and Ruttens 2017) }\end{array}$ \\
\hline Arsenic, inorganic & Hizikia fusiforme (hijiki) & $\begin{array}{c}\text { Soaked water or } \mathrm{NaCl} \\
\text { solution }(0-2 \%) \text {, then } \\
\text { boiled }\end{array}$ & $20 \%$ & LC-ICP-MS & (Park et al. 2019) \\
\hline Copper & Laminaria (kombu) & Boiled & $80 \%$ & ICP-MS & (García-Sartal et al. 2013) \\
\hline Copper & Undaria (wakame) & Boiled & $20 \%$ & ICP-MS & (García-Sartal et al. 2013) \\
\hline Copper & Porphyra (nori) & Boiled & $40 \%$ & ICP-MS & (García-Sartal et al. 2013) \\
\hline Copper & Ulva (sea lettuce) & Boiled & $50 \%$ & ICP-MS & (García-Sartal et al. 2013) \\
\hline lodine & Laminaria (kelp) & Boiled & $10 \%$ & ICP-MS & (Chung et al. 2013) \\
\hline lodine & A. esculenta & $\begin{array}{l}\text { Dehydrated, rehydrated, } \\
\text { then boiled }\end{array}$ & $75 \%$ & LC-DAD & (Nitschke and Stengel 2016) \\
\hline lodine & P. palmata & $\begin{array}{l}\text { Dehydrated, rehydrated, } \\
\text { then boiled }\end{array}$ & $30 \%$ & LC-DAD & (Nitschke and Stengel 2016) \\
\hline lodine & U. intestinalis & $\begin{array}{c}\text { Dehydrated, rehydrated, } \\
\text { then boiled }\end{array}$ & $10 \%$ & LC-DAD & (Nitschke and Stengel 2016) \\
\hline Iron & Porphyra (nori) & Dried, then toasted & $120 \%$ & GF-AAS & $\begin{array}{c}\text { (Masuda, Yamamoto, and } \\
\text { Toyohara 2015) }\end{array}$ \\
\hline Iron & Laminaria (kombu) & Boiled & $70 \%$ & ICP-MS & (García-Sartal et al. 2013) \\
\hline
\end{tabular}




\begin{tabular}{|c|c|c|c|c|c|}
\hline Iron & Undaria (wakame) & Boiled & $90 \%$ & ICP-MS & (García-Sartal et al. 2013) \\
\hline Iron & Porphyra (nori) & Boiled & $70 \%$ & ICP-MS & (García-Sartal et al. 2013) \\
\hline Iron & Ulva (sea lettuce) & Boiled & $50 \%$ & ICP-MS & (García-Sartal et al. 2013) \\
\hline Selenium & Laminaria (kombu) & Boiled & $50 \%$ & ICP-MS & (García-Sartal et al. 2013) \\
\hline Selenium & Undaria (wakame) & Boiled & $80 \%$ & ICP-MS & (García-Sartal et al. 2013) \\
\hline Selenium & Porphyra (nori) & Boiled & $50 \%$ & ICP-MS & (García-Sartal et al. 2013) \\
\hline Selenium & Ulva (sea lettuce) & Boiled & $30 \%$ & ICP-MS & (García-Sartal et al. 2013) \\
\hline Zinc & Laminaria (kombu) & Boiled & $110 \%$ & ICP-MS & (García-Sartal et al. 2013) \\
\hline Zinc & Undaria (wakame) & Boiled & $70 \%$ & ICP-MS & (García-Sartal et al. 2013) \\
\hline Zinc & Porphyra (nori) & Boiled & No change & ICP-MS & (García-Sartal et al. 2013) \\
\hline Zinc & Ulva (sea lettuce) & Boiled & $60 \%$ & ICP-MS & (García-Sartal et al. 2013) \\
\hline
\end{tabular}

${ }^{a}$ Abbreviations used: DAD, diode array detector; GF-AAS, graphite furnace-atomic absorption spectroscopy; iAs, inorganic arsenic; ICP-MS, inductively coupled plasma-mass spectrometry; LC, liquid chromatography

${ }^{b}$ Retention was estimated by calculating [element concentration after processing]/[element concentration before processing] ${ }^{\star} 100 \%$. Values greater than $100 \%$ may indicate enhanced extractability from a modified food matrix due to processing. 
In addition to the direct analysis of heavy metals in algae, it is important to consider how food processing can affect levels of these elements in algae. Several studies have demonstrated that iAs can be decreased in foods after processing, including use of typical in-home methods. For instance, a study performed in Japan that tested the effect of soaking and cooking hijiki on levels of As species found that levels of total arsenic were reduced by $~ 90 \%$ after soaking and subsequent boiling for $20 \mathrm{~min}$ (Ichikawa et al. 2006). Another study tested how cooking nori and hijiki by soaking and boiling affected As levels (Cheyns et al. 2017). The authors found that cooking nori reduced levels of iAs by only $6-24 \%$ —although iAs in nori was already low $(<0.15$ $\mathrm{mg} / \mathrm{kg}$ ) - but cooking hijiki reduced iAs by $70 \%$. In another study on hijiki, a $50 \%$ reduction in iAs was observed after boiling, but $\sim 80 \%$ was reduced after the seaweed had first been soaked in a $2 \% \mathrm{NaCl}$ solution and then afterwards boiled (Park et al. 2019). The addition of $\mathrm{NaCl}$ to the soaking water may promote solubilization of iAs, which is consistent with other research demonstrating that chloride ions can solubilize heavy metals (Abt and Robin 2020). Due to several other studies indicating that reduction of iAs in other foodstuffs can be obtained through rinsing/washing and boiling, this effect appears to be a robust phenomenon (Gray et al. 2016, Redan et al. 2019, Redan 2020). Together, these results may help in producing a product with As concentrations more likely to be within compendial standards or potential regulatory limits.

Although research has suggested that levels of As can be reduced after cooking, these processes may also be able to drive conversion of organic forms of As to iAs species, according to preliminary studies. Conversion of organic arsenic to iAs has thus far been reported to occur in shellfish under certain conditions, including boiling (Liao et al. 2018). These experiments suggest that it is important to more thoroughly characterize any conversion of As species in algae and other seafood to provide strategies for prevention of species conversion. 
Aside from As, there are some studies that have investigated the effect of processing on in vitro bioaccessibility of metals from algae. In a study that examined in vitro bioaccessibility, a 3-phase model of digestion found that kelp cooked in a microwave at 900W exhibited no difference in Cd bioaccessibility compared to an unprocessed control (Wang, Duan, and Teng 2014). In contrast, a study that tested the effect of cooking kombu by boiling found that in vitro bioaccessibility of rare earth elements significantly increased from approximately $30 \%$ before cooking to $80 \%$ after cooking (Liu et al. 2017). Thus, as with other types of foods, processing may promote release of metals from the food matrix during digestion, but these results will need to be followed up with in vivo studies to confirm whether these results translate to animals and humans.

\section{Summary \& Conclusion}

Edible algae contain a considerable amount of various phytochemicals and nutritional compounds, such as important minerals and water- and fat-soluble vitamins. Although limited amounts of algae are consumed in its fresh, unprocessed state, the vast majority is typically subjected to multiple stages of processing, such as drying and other forms of thermal treatments before being made available to the consumer. There have also more recently been efforts to pursue use of technologies such as HPP and cold plasma to process algae. The research presented in this review indicate that each of these processing stages can significantly impact levels of key nutritional constituents, phytochemicals, and metal contaminants, and have particular aspects that can provide certain advantages or limitations depending on the desired outcome of processing (summarized in Figure 4). As such, ongoing algae research should further explore 
how processing affects not only important phytochemicals and nutrients in these products, but also potential contaminants. Additionally, efforts to further characterize and identify phenolic compounds in algae will be crucial to better assess how processing affects concentrations of these phytochemicals. Because the demand for algae-based foods is projected to increase rapidly in the future, it is critical that research efforts continue to focus on the major chemical constituents in algae by characterizing how post-harvest processing affects both the retention of important nutritional compounds and reduction of potential contaminants.

There are still many gaps in this area of literature that leave room open for further research. One area in particular is related to characterization of individual phenolic compounds and pigments in algae and how processing affects these components. Much of the research in this review has focused on studies that utilized nonspecific assays or methodologies that may be affected by analytical interferences. Studies designed to use analytical instrumentation that can quantitate and characterize individual compounds (e.g.,, HPLC or mass spectrometry-based detection) is needed to move this field forward. We also have noted that a limitation of the literature is that it has only largely considered the effect of thermal processing on the concentrations of phytochemical components in algae, but not how processing ultimately affects the bioavailability of these compounds. Because thermal processing has repeatedly been shown to affect bioavailability of nutritional and phytochemical constituents in other food matrixes, it is expected that future research may find that bioavailability of these compounds may also be altered in a processed algae matrix. Although further research is needed on thermally processed algae products, the existing data should be considered to inform consumers and to optimize processing to increase retention of nutritional components while also limiting contaminants. 
Taken together, these developments should make algae products well-positioned to constitute an ever-larger part of dietary consumption.
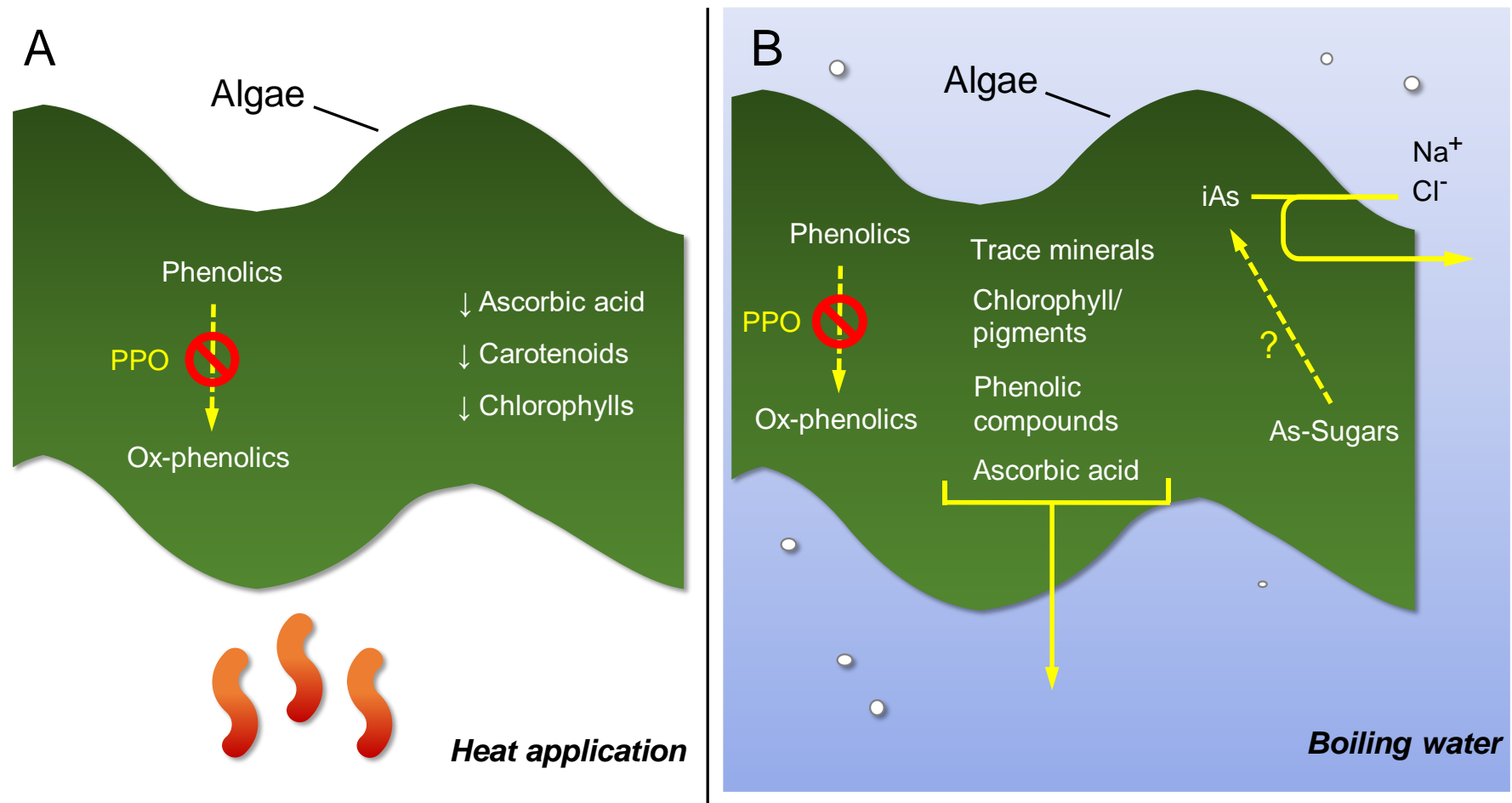

Figure 4. Major potential effects of dry and wet thermal processing on nutrient, phytochemical, and metal contaminant concentrations in algae. (A) Dry heat can induce degradation of ascorbic acid (vitamin C), carotenoids, and chlorophyll pigments. Heat can increase phenolic compound retention via denaturation of polyphenol oxidase. (B) Cooking in boiling water reduces watersoluble compounds including ascorbic acid, phenolic compounds, certain chlorophyll/pigment compounds, and trace metals (both nutrients and contaminants). These decreases may be due to migration into the water phase. Addition of sodium chloride $(\mathrm{NaCl})$ to cooking water may increase inorganic arsenic (iAs) release. Heat may convert arsenosugars (As-Sugars) to iAs, although this has not yet been definitively shown. Abbreviations used: As-Sugars, arsenosugars; iAs, inorganic arsenic; PPO, polyphenol oxidase; ox-phenolics, oxidized phenolic compounds. 


\section{References}

Abbott, I. A. 1978. The uses of seaweed as food in Hawaii. Economic Botany 32 (4):409-412.

Abbott, I. A. 1984. Limu: An ethnobotanical study of some Hawaiian seaweeds. Lawai, Kauai, Hawaii: National Tropical Botanical Garden.

Abt, E., and L. P. Robin. 2020. Perspective on cadmium and lead in cocoa and chocolate. Journal of Agricultural and Food Chemistry. doi: 10.1021/acs.jafc.9b08295.

Agustini, T. W., M. Suzery, D. Sutrisnanto, and W. F. Ma'ruf. 2015. Comparative study of bioactive substances extracted from fresh and dried Spirulina sp. Procedia Environmental Sciences 23:282289.

Almela, C., S. Algora, V. Benito, M. Clemente, V. Devesa, M. Suner, D. Velez, and R. Montoro. 2002. Heavy metal, total arsenic, and inorganic arsenic contents of algae food products. Journal of Agricultural and Food Chemistry 50 (4):918-923.

Ambarsari, I., B. Brown, R. Barlow, G. Britton, and D. Cummings. 1997. Fluctuations in algal chlorophyll and carotenoid pigments during solar bleaching in the coral Goniastrea aspera at Phuket, Thailand. Marine Ecology Progress Series 159:303-307.

Ambati, R. R., D. Gogisetty, R. G. Aswathanarayana, S. Ravi, P. N. Bikkina, L. Bo, and S. Yuepeng. 2018. Industrial potential of carotenoid pigments from microalgae: Current trends and future prospects. Critical Reviews in Food Science and Nutrition:1-22.

Amorim, K., M.-A. Lage-Yusty, and J. López-Hernández. 2012. Changes in bioactive compounds content and antioxidant activity of seaweed after cooking processing. CyTA-Journal of Food 10 (4):321324.

Angell, A. R., S. F. Angell, R. de Nys, and N. A. Paul. 2016. Seaweed as a protein source for monogastric livestock. Trends in Food Science \& Technology 54:74-84.

Arasaki, S., and T. Arasaki. 1983. Vegetables from the Sea. Tokyo: Japan Publications.

Asai, A., L. Yonekura, and A. Nagao. 2008. Low bioavailability of dietary epoxyxanthophylls in humans. British Journal of Nutrition 100 (2):273-277.

Badmus, U. O., M. A. Taggart, and K. G. Boyd. 2019. The effect of different drying methods on certain nutritionally important chemical constituents in edible brown seaweeds. Journal of Applied Phycology 31 (6):3883-3897.

Banach, J., E. Hoek-van den Hil, and H. van der Fels-Klerx. 2020. Food safety hazards in the European seaweed chain. Comprehensive Reviews in Food Science and Food Safety 19 (2):332-364.

Bangmei, X., and I. A. Abbott. 1987. Edible seaweeds of China and their place in the Chinese diet. Economic Botany 41 (3):341-353.

Bansal, V., K. Jabeen, P. Rao, P. Prasad, and S. K. Yadav. 2019. Effect of high pressure processing (HPP) on microbial safety, physicochemical properties, and bioactive compounds of whey-based sweet lime (whey-lime) beverage. Journal of Food Measurement and Characterization 13 (1):454-465.

Becker, E. 2007. Micro-algae as a source of protein. Biotechnology Advances 25 (2):207-210.

Beer, S., and A. Eshel. 1985. Determining phycoerythrin and phycocyanin concentrations in aqueous crude extracts of red algae. Marine and Freshwater Research 36 (6):785-792.

Beyrer, M., M. Pina-Perez, D. Martinet, and W. Andlauer. 2020. Cold plasma processing of powdered Spirulina algae for spore inactivation and preservation of bioactive compounds. Food Control:107378. 
Birch, D., K. Skallerud, and N. Paul. 2019a. Who are the future seaweed consumers in a Western society? Insights from Australia. British Food Journal 121 (2):603-615.

Birch, D., K. Skallerud, and N. Paul. 2019b. Who eats seaweed? An Australian perspective. Journal of International Food \& Agribusiness Marketing 31 (4):329-351.

Bouga, M., and E. Combet. 2015. Emergence of seaweed and seaweed-containing foods in the UK: focus on labeling, iodine content, toxicity and nutrition. Foods 4 (2):240-253.

Boussiba, S., W. Bing, J.-P. Yuan, A. Zarka, and F. Chen. 1999. Changes in pigments profile in the green alga Haeamtococcus pluvialis exposed to environmental stresses. Biotechnology Letters 21 (7):601-604.

Boussiba, S., and A. Vonshak. 1991. Astaxanthin accumulation in the green alga Haematococcus pluvialis. Plant and Cell Physiology 32 (7):1077-1082.

Brandon, E. F., P. J. Janssen, and L. de Wit-Bos. 2014. Arsenic: bioaccessibility from seaweed and rice, dietary exposure calculations and risk assessment. Food Additives \& Contaminants: Part A 31 (12):1993-2003.

Brown, E. M., P. J. Allsopp, P. J. Magee, C. I. Gill, S. Nitecki, C. R. Strain, and E. M. McSorley. 2014. Seaweed and human health. Nutrition Reviews 72 (3):205-216.

Callegari, A., S. Bolognesi, D. Cecconet, and A. G. Capodaglio. 2020. Production technologies, current role, and future prospects of biofuels feedstocks: A state-of-the-art review. Critical Reviews in Environmental Science and Technology 50 (4):384-436.

Canadian Food Inspection Agency. 2019. "Inorganic arsenic and hijiki seaweed consumption." accessed 2020 APR 16. https://www.inspection.gc.ca/food-safety-for-industry/information-forconsumers/fact-sheets-and-infographics/products-and-risks/chemical-hazards/inorganicarsenic/eng/1332268146718/1332268231124.

Careri, M., L. Furlattini, A. Mangia, M. Musci, E. Anklam, A. Theobald, and C. Von Holst. 2001. Supercritical fluid extraction for liquid chromatographic determination of carotenoids in Spirulina Pacifica algae: A chemometric approach. Journal of Chromatography A 912 (1):61-71.

Cha, K. H., S. Y. Koo, D.-G. Song, and C.-H. Pan. 2012. Effect of microfluidization on bioaccessibility of carotenoids from Chlorella ellipsoidea during simulated digestion. Journal of Agricultural and Food Chemistry 60 (37):9437-9442.

Chakraborty, S., N. S. Hulle, K. Jabeen, and P. Rao. 2017. "Effect of combined high pressuretemperature treatments on bioactive compounds in fruit purées." In Innovative Processing Technologies for Foods with Bioactive Compounds, edited by Jorge J Moreno, 105-130. Taylor \& Francis.

Chan, J. C.-C., P. C.-K. Cheung, and P. O. Ang. 1997. Comparative studies on the effect of three drying methods on the nutritional composition of seaweed Sargassum hemiphyllum (Turn.) C. Ag. Journal of Agricultural and Food Chemistry 45 (8):3056-3059.

Charles, A. L., K. Sridhar, and M. A. Alamsjah. 2020. Effect of drying techniques on color and bioactive potential of two commercial edible Indonesian seaweed cultivars. Journal of Applied Phycology 32:563-572.

Chen, K., and M. Roca. 2018. Cooking effects on chlorophyll profile of the main edible seaweeds. Food Chemistry 266:368-374.

Chen, K., and M. Roca. 2019. Cooking effects on bioaccessibility of chlorophyll pigments of the main edible seaweeds. Food Chemistry 295:101-109. 
Chen, X., M. Wu, Q. Yang, and S. Wang. 2017. Preparation, characterization of food grade phycobiliproteins from Porphyra haitanensis and the application in liposome-meat system. $L W T$ Food Science and Technology 77:468-474.

Cheyns, K., N. Waegeneers, T. Van de Wiele, and A. Ruttens. 2017. Arsenic release from foodstuffs upon food preparation. Journal of Agricultural and Food Chemistry 65 (11):2443-2453.

Chi, N. T. L., P. A. Duc, T. Mathimani, and A. Pugazhendhi. 2019. Evaluating the potential of green alga Chlorella sp. for high biomass and lipid production in biodiesel viewpoint. Biocatalysis and Agricultural Biotechnology 17:184-188.

Chung, S., A. Chan, Y. Xiao, V. Lin, and Y. Ho. 2013. Iodine content in commonly consumed food in Hong Kong and its changes due to cooking. Food Additives and Contaminants: Part B 6 (1):2429.

Cian, R. E., M. A. Fajardo, M. Alaiz, J. Vioque, R. J. González, and S. R. Drago. 2014. Chemical composition, nutritional and antioxidant properties of the red edible seaweed Porphyra columbina. International Journal of Food Sciences and Nutrition 65 (3):299-305.

Cofrades, S., I. López-Lopez, L. Bravo, C. Ruiz-Capillas, S. Bastida, M. T. Larrea, and F. JiménezColmenero. 2010. Nutritional and antioxidant properties of different brown and red Spanish edible seaweeds. Food Science and Technology International 16 (5):361-370.

Corona, G., M. M. Coman, Y. Guo, S. Hotchkiss, C. Gill, P. Yaqoob, J. P. Spencer, and I. Rowland. 2017. Effect of simulated gastrointestinal digestion and fermentation on polyphenolic content and bioactivity of brown seaweed phlorotannin-rich extracts. Molecular Nutrition \& Food Research 61 (11):1700223.

Cox, S., N. Abu-Ghannam, and S. Gupta. 2012. Effect of processing conditions on phytochemical constituents of edible Irish seaweed Himanthalia elongata. Journal of Food Processing and Preservation 36 (4):348-363.

Croft, M. T., A. D. Lawrence, E. Raux-Deery, M. J. Warren, and A. G. Smith. 2005. Algae acquire vitamin B 12 through a symbiotic relationship with bacteria. Nature 438 (7064):90-93.

Dagnelie, P.-C., W. A. van Staveren, and H. van den Berg. 1991. Vitamin B-12 from algae appears not to be bioavailable. American Journal of Clinical Nutrition 53 (3):695-697.

Dawczynski, C., R. Schubert, and G. Jahreis. 2007. Amino acids, fatty acids, and dietary fibre in edible seaweed products. Food Chemistry 103 (3):891-899.

Debbarma, J., P. Viji, B. Rao, and M. Prasad. 2017. Nutritional and physical characteristics of noodles incorporated with green sea weed (Ulva reticulata) and fish (Pangasianodon hypophthalmus) mince. Indian Journal of Fisheries 64 (2):90-95.

del Olmo, A., A. Picon, and M. Nuñez. 2020. Preservation of five edible seaweeds by high pressure processing: effect on microbiota, shelf life, colour, texture and antioxidant capacity. Algal Research 49:101938.

Delchier, N., M. Reich, and C. M. Renard. 2012. Impact of cooking methods on folates, ascorbic acid and lutein in green beans (Phaseolus vulgaris) and spinach (Spinacea oleracea). LWT-Food Science and Technology 49 (2):197-201.

Dewi, E. N. 2011. Quality evaluation of dried noodle with seaweeds puree substitution. Journal of Coastal Development 14 (2):151-158.

Dey, S., and V. K. Rathod. 2013. Ultrasound assisted extraction of $\beta$-carotene from Spirulina platensis. Ultrasonics Sonochemistry 20 (1):271-276. 
Dillehay, T. D., C. Ramirez, M. Pino, M. B. Collins, J. Rossen, and J. Pino-Navarro. 2008. Monte Verde: seaweed, food, medicine, and the peopling of South America. Science 320 (5877):784-786.

Domínguez-González, M. R., G. M. Chiocchetti, P. Herbello-Hermelo, D. Vélez, V. Devesa, and P. Bermejo-Barrera. 2017. Evaluation of iodine bioavailability in seaweed using in vitro methods. Journal of Agricultural and Food Chemistry 65 (38):8435-8442.

Edelmann, M., S. Aalto, B. Chamlagain, S. Kariluoto, and V. Piironen. 2019. Riboflavin, niacin, folate and vitamin B12 in commercial microalgae powders. Journal of Food Composition and Analysis 82:103226.

EFSA Panel on Contaminants in the Food Chain (CONTAM). 2009. Scientific opinion on arsenic in food. EFSA Journal 7 (10):1351.

Ferraces-Casais, P., M. Lage-Yusty, A. R.-B. de Quirós, and J. López-Hernández. 2012. Evaluation of bioactive compounds in fresh edible seaweeds. Food Analytical Methods 5 (4):828-834.

Ferruzzi, M. G., M. L. Failla, and S. J. Schwartz. 2001. Assessment of degradation and intestinal cell uptake of carotenoids and chlorophyll derivatives from spinach puree using an in vitro digestion and Caco-2 human cell model. Journal of Agricultural and Food Chemistry 49 (4):2082-2089.

Food and Agriculture Organization of the United Nations (FAO). 2020. "Consumption of Fish and Fishery Products." accessed September 4, 2020. http://www.fao.org/faostat/en/\#data/CL.

Food Chemicals Codex. 2016. Kelp. 10th ed. Rockville, MD: United States Pharmacopeial Convention.

Food Standards Australia New Zealand. 2016. Imported food risk statement: Hijiki seaweed and inorganic arsenic.

Gallego, R., K. Arena, P. Dugo, L. Mondello, E. Ibáñez, and M. Herrero. 2020. Application of compressed fluid-based extraction and purification procedures to obtain astaxanthin-enriched extracts from Haematococcus pluvialis and characterization by comprehensive two-dimensional liquid chromatography coupled to mass spectrometry. Analytical and Bioanalytical Chemistry 412 (3):589-599.

García-Casal, M. N., A. C. Pereira, I. Leets, J. Ramírez, and M. F. Quiroga. 2007. High iron content and bioavailability in humans from four species of marine algae. Journal of Nutrition 137 (12):26912695.

García-Sartal, C., M. del Carmen Barciela-Alonso, A. Moreda-Piñeiro, and P. Bermejo-Barrera. 2013. Study of cooking on the bioavailability of $\mathrm{As}, \mathrm{Co}, \mathrm{Cr}, \mathrm{Cu}, \mathrm{Fe}, \mathrm{Ni}, \mathrm{Se}$ and $\mathrm{Zn}$ from edible seaweed. Microchemical Journal 108:92-99.

Gómez, I., F. L. Figueroa, P. Huovinen, N. Ulloa, and V. Morales. 2005. Photosynthesis of the red alga Gracilaria chilensis under natural solar radiation in an estuary in southern Chile. Aquaculture 244 (1-4):369-382.

Gray, P. J., S. D. Conklin, T. I. Todorov, and S. M. Kasko. 2016. Cooking rice in excess water reduces both arsenic and enriched vitamins in the cooked grain. Food Additives and Contaminants: Part A 33 (1):78-85.

Grosshagauer, S., K. Kraemer, and V. Somoza. 2020. The true value of Spirulina. Journal of Agricultural and Food Chemistry 68 (14):4109-4115.

Guo, B., T. Oliviero, V. Fogliano, Y. Ma, F. Chen, and E. Capuano. 2019. Gastrointestinal bioaccessibility and colonic fermentation of fucoxanthin from the extract of the microalga Nitzschia laevis. Journal of Agricultural and Food Chemistry. 
Gupta, S., S. Cox, and N. Abu-Ghannam. 2011. Effect of different drying temperatures on the moisture and phytochemical constituents of edible Irish brown seaweed. LWT-Food Science and Technology 44 (5):1266-1272.

Hamid, S. S., M. Wakayama, Y. Ashino, R. Kadowaki, T. Soga, and M. Tomita. 2020. Effect of blanching on the concentration of metabolites in two parts of Undaria pinnatifida, Wakame (leaf) and Mekabu (sporophyll). Algal Research 47:101829.

Hart, G. M., T. Ticktin, D. Kelman, A. D. Wright, and N. Tabandera. 2014. Contemporary gathering practice and antioxidant benefit of wild seaweeds in Hawai'i. Economic Botany 68 (1):30-43.

Haskell-Ramsay, C. F., P. A. Jackson, F. L. Dodd, J. S. Forster, J. Bérubé, C. Levinton, and D. O. Kennedy. 2018. Acute post-prandial cognitive effects of brown seaweed extract in humans. Nutrients 10 (1):85.

He, P., J. Duncan, and J. Barber. 2007. Astaxanthin accumulation in the green alga Haematococcus pluvialis: effects of cultivation parameters. Journal of Integrative Plant Biology 49 (4):447-451.

Health Canada. 2017. "Health Canada's Proposal to Update the Maximum Levels for Arsenic in Apple Juice and Water in Sealed Containers in the List of Contaminants and Other Adulterating Substances in Foods." accessed 21 December 2019. https://www.canada.ca/content/dam/hcsc/migration/hc-sc/fn-an/alt_formats/pdf/consult/nop-avp-c-2017-1/nop-avp-c-2017-1-eng.pdf.

Ho, K. K., T. C. Haufe, M. G. Ferruzzi, and A. P. Neilson. 2018. Production and polyphenolic composition of tea. Nutrition Today 53 (6):268-278.

Hoek, C., D. Mann, H. M. Jahns, and M. Jahns. 1995. Algae: An introduction to phycology: Cambridge university press.

Hu, C.-C., J.-T. Lin, F.-J. Lu, F.-P. Chou, and D.-J. Yang. 2008. Determination of carotenoids in Dunaliella salina cultivated in Taiwan and antioxidant capacity of the algal carotenoid extract. Food Chemistry 109 (2):439-446.

Humphrey, A. 2004. Chlorophyll as a color and functional ingredient. Journal of Food Science 69 (5):C422-C425.

Hwang, Y., S. Park, G. Park, S. Choi, and M. Kim. 2010. Total arsenic, mercury, lead, and cadmium contents in edible dried seaweed in Korea. Food Additives and Contaminants: Part B 3 (1):7-13.

Ichikawa, S., M. Kamoshida, K. i. Hanaoka, M. Hamano, T. Maitani, and T. Kaise. 2006. Decrease of arsenic in edible brown algae Hijikia fusiforme by the cooking process. Applied Organometallic Chemistry 20 (9):585-590.

Irshad, M., A. A. Myint, M. E. Hong, J. Kim, and S. J. Sim. 2019. One-pot, simultaneous cell wall disruption and complete extraction of astaxanthin from Haematococcus pluvialis at room temperature. ACS Sustainable Chemistry \& Engineering 7 (16):13898-13910.

Jacobsen, C., A.-D. M. Sørensen, S. L. Holdt, C. C. Akoh, and D. B. Hermund. 2019. Source, extraction, characterization, and applications of novel antioxidants from seaweed. Annual Review of Food Science and Technology 10:541-568.

Jensen, A. 1969. Tocopherol content of seaweed and seaweed meal: III. Influence of processing and storage on the content of tocopherols, carotenoids and ascorbic acid in seaweed meal. Journal of the Science of Food and Agriculture 20 (10):622-626.

Jiménez-Escrig, A., I. Jiménez-Jiménez, R. Pulido, and F. Saura-Calixto. 2001. Antioxidant activity of fresh and processed edible seaweeds. Journal of the Science of Food and Agriculture 81 (5):530534. 
Kakita, H., and H. Obika. 2017. A simple pretreatment and HPLC method for $\beta$-carotene determination in edible seaweeds. Algal Resources 10 (2):59-66.

Klamczynska, B., and W. Mooney. 2017. "Heterotrophic microalgae: a scalable and sustainable protein source." In Sustainable protein sources, 327-339. Elsevier.

Kobayashi, M., T. Kakizono, N. Nishio, and S. Nagai. 1992. Effects of light intensity, light quality, and illumination cycle on astaxanthin formation in a green alga, Haematococcus pluvialis. Journal of Fermentation and Bioengineering 74 (1):61-63.

Kondzior, P., D. Tyniecki, and A. Butarewicz. 2019. "Influence of Color Temperature of White LED Diodes and Illumination Intensity on the Content of Photosynthetic Pigments in Chlorella vulgaris Algae Cells." Multidisciplinary Digital Publishing Institute Proceedings.

Kong, W., N. Liu, J. Zhang, Q. Yang, S. Hua, H. Song, and C. Xia. 2014. Optimization of ultrasoundassisted extraction parameters of chlorophyll from Chlorella vulgaris residue after lipid separation using response surface methodology. Journal of Food Science and Technology 51 (9):2006-2013.

Kose, A., M. O. Ozen, M. Elibol, and S. S. Oncel. 2017. Investigation of in vitro digestibility of dietary microalga Chlorella vulgaris and cyanobacterium Spirulina platensis as a nutritional supplement. 3 Biotech 7 (3):170.

Kwon, P. S., H. Oh, S.-J. Kwon, W. Jin, F. Zhang, K. Fraser, J. J. Hong, R. J. Linhardt, and J. S. Dordick. 2020. Sulfated polysaccharides effectively inhibit SARS-CoV-2 in vitro. Cell Discovery 6 (1):14.

Leser, S. 2013. The 2013 FAO report on dietary protein quality evaluation in human nutrition: recommendations and implications. Nutrition Bulletin 38 (4):421-428.

Li, L., Y. Zhao, G. Han, J. Guo, Z. Meng, and M. Chen. 2020. Progress in the study and use of seawater vegetables. Journal of Agricultural and Food Chemistry.

Li, M., K. K. Ho, M. Hayes, and M. G. Ferruzzi. 2019. The roles of food processing in translation of dietary guidance for whole grains, fruits, and vegetables. Annual Review of Food Science and Technology 10:569-596.

Li, X., Y. Chen, J. Ye, F. Fu, G. R. Pokhrel, H. Zhang, Y. Zhu, and G. Yang. 2017. Determination of different arsenic species in food-grade spirulina powder by ion chromatography combined with inductively coupled plasma mass spectrometry. Journal of Separation Science 40 (18):36553661.

Liao, W., G. Wang, K. Li, and W. Zhao. 2018. Change of arsenic speciation in shellfish after cooking and gastrointestinal digestion. Journal of Agricultural and Food Chemistry 66 (29):7805-7814.

Lim, P.-E., L.-E. Yang, J. Tan, C. A. Maggs, and J. Brodie. 2017. Advancing the taxonomy of economically important red seaweeds (Rhodophyta). European Journal of Phycology 52 (4):438451.

Ling, A. L. M., S. Yasir, P. Matanjun, and M. F. A. Bakar. 2015. Effect of different drying techniques on the phytochemical content and antioxidant activity of Kappaphycus alvarezii. Journal of Applied Phycology 27 (4):1717-1723.

Liu, C., H. Lin, N. Mi, Y. Xu, Y. Song, Z. Liu, and J. Sui. 2017. Effect of thermal processing on the concentration and bioaccessibility of rare earth elements in seaweed and oyster. Journal of Food Processing and Preservation 41 (6):e13259.

López-Hortas, L., L. Gannon, R. Moreira, F. Chenlo, H. Domínguez, and M. Torres. 2018. Microwave hydrodiffusion and gravity (MHG) processing of Laminaria ochroleuca brown seaweed. Journal of Cleaner Production 197:1108-1116. 
López-Hortas, L., M. Gely, E. Falqué, H. Domínguez, and M. D. Torres. 2019. Alternative environmental friendly process for dehydration of edible Undaria pinnatifida brown seaweed by microwave hydrodiffusion and gravity. Journal of Food Engineering 261:15-25.

Ludikhuyze, L., A. Van Loey, Indrawati, C. Smout, and M. Hendrickx. 2003. Effects of combined pressure and temperature on enzymes related to quality of fruits and vegetables: From kinetic information to process engineering aspects. Critical Reviews in Food Science and Nutrition 43 (5):527-586.

Luvonga, C., C. A. Rimmer, L. L. Yu, and S. B. Lee. 2020. Analytical methodologies for the determination of organoarsenicals in Edible Marine Species: A review. Journal of Agricultural and Food Chemistry.

MacArtain, P., C. I. Gill, M. Brooks, R. Campbell, and I. R. Rowland. 2007. Nutritional value of edible seaweeds. Nutrition Reviews 65 (12):535-543.

Maeda, H., S. Fukuda, H. Izumi, and N. Saga. 2018. Anti-oxidant and fucoxanthin contents of brown alga Ishimozuku (Sphaerotrichia divaricata) from the West Coast of Aomori, Japan. Marine Drugs 16 (8):255.

Maehre, H. K., G. K. Edvinsen, K.-E. Eilertsen, and E. O. Elvevoll. 2016. Heat treatment increases the protein bioaccessibility in the red seaweed dulse (Palmaria palmata), but not in the brown seaweed winged kelp (Alaria esculenta). Journal of Applied Phycology 28 (1):581-590.

Malec, M., J.-M. Le Quere, H. Sotin, K. Kolodziejczyk, R. Bauduin, and S. Guyot. 2014. Polyphenol profiling of a red-fleshed apple cultivar and evaluation of the color extractability and stability in the juice. Journal of Agricultural and Food Chemistry 62 (29):6944-6954.

Martínez, J. M., Z. Gojkovic, L. Ferro, M. Maza, I. Álvarez, J. Raso, and C. Funk. 2019. Use of pulsed electric field permeabilization to extract astaxanthin from the Nordic microalga Haematococcus pluvialis. Bioresource Technology 289:121694.

Masuda, T., A. Yamamoto, and H. Toyohara. 2015. The iron content and ferritin contribution in fresh, dried, and toasted nori, Pyropia yezoensis. Bioscience, Biotechnology, and Biochemistry 79 (1):74-81.

McHugh, D. 2003. A guide to the seaweed industry FAO Fisheries Technical Paper 441. Food and Agriculture Organization of the United Nations, Rome.

Mouritsen, O. G., P. Rhatigan, and J. L. Pérez-Lloréns. 2018. World cuisine of seaweeds: science meets gastronomy. International Journal of Gastronomy and Food Science 14:55-65.

Neoh, Y. Y., P. Matanjun, and J. S. Lee. 2016. Comparative study of drying methods on chemical constituents of Malaysian red seaweed. Drying Technology 34 (14):1745-1751.

Nisizawa, K., H. Noda, R. Kikuchi, and T. Watanabe. 1987. The main seaweed foods in Japan. Hydrobiologia 151 (1):5-29.

Nitschke, U., and D. B. Stengel. 2016. Quantification of iodine loss in edible Irish seaweeds during processing. Journal of Applied Phycology 28 (6):3527-3533.

Olaizola, M. 2000. Commercial production of astaxanthin from Haematococcus pluvialis using 25,000liter outdoor photobioreactors. Journal of Applied Phycology 12 (3-5):499-506.

Oliveira, C. M., A. C. S. Ferreira, V. De Freitas, and A. M. Silva. 2011. Oxidation mechanisms occurring in wines. Food Research International 44 (5):1115-1126.

Ota, S., A. Morita, S. Ohnuki, A. Hirata, S. Sekida, K. Okuda, Y. Ohya, and S. Kawano. 2018. Carotenoid dynamics and lipid droplet containing astaxanthin in response to light in the green alga Haematococcus pluvialis. Scientific Reports 8 (1):1-10. 
Park, G.-y., D.-e. Kang, M. Davaatseren, C. Shin, G.-J. Kang, and M.-S. Chung. 2019. Reduction of total, organic, and inorganic arsenic content in Hizikia fusiforme (hijiki). Food Science and Biotechnology 28 (2):615-622.

Park, W., H.-J. Kim, M. Li, D. Lim, J. Kim, S.-S. Kwak, C.-M. Kang, M. Ferruzzi, and M.-J. Ahn. 2018. Two classes of pigments, carotenoids and c-phycocyanin, in Spirulina powder and their antioxidant activities. Molecules 23 (8):2065.

Pereira, T., S. Barroso, S. Mendes, R. A. Amaral, J. R. Dias, T. Baptista, J. A. Saraiva, N. M. Alves, and M. M. Gil. 2020. Optimization of phycobiliprotein pigments extraction from red algae Gracilaria gracilis for substitution of synthetic food colorants. Food Chemistry:126688.

Poojary, M. M., F. J. Barba, B. Aliakbarian, F. Donsì, G. Pataro, D. A. Dias, and P. Juliano. 2016. Innovative alternative technologies to extract carotenoids from microalgae and seaweeds. Marine Drugs 14 (11):214.

Porse, H., and B. Rudolph. 2017. The seaweed hydrocolloid industry: 2016 updates, requirements, and outlook. Journal of applied phycology 29 (5):2187-2200.

Rajauria, G., A. K. Jaiswal, N. Abu-Ghannam, and S. Gupta. 2010. Effect of hydrothermal processing on colour, antioxidant and free radical scavenging capacities of edible Irish brown seaweeds. International Journal of Food Science \& Technology 45 (12):2485-2493.

Rawson, A., A. Patras, B. Tiwari, F. Noci, T. Koutchma, and N. Brunton. 2011. Effect of thermal and non thermal processing technologies on the bioactive content of exotic fruits and their products: Review of recent advances. Food Research International 44 (7):1875-1887.

Redan, B. W. 2020. Processing aids in food and beverage manufacturing: Potential source of elemental and trace metal contaminants. Journal of Agricultural and Food Chemistry. doi: 10.1021/acs.jafc.9b08066.

Redan, B. W., K. K. Buhman, J. A. Novotny, and M. G. Ferruzzi. 2016. Altered transport and metabolism of phenolic compounds in obesity and diabetes: implications for functional food development and assessment. Advances in Nutrition 7 (6):1090-1104.

Redan, B. W., J. E. Jablonski, C. Halverson, J. Jaganathan, M. A. Mabud, and L. S. Jackson. 2019. Factors affecting transfer of the heavy metals arsenic, lead, and cadmium from diatomaceousearth filter aids to alcoholic beverages during laboratory-scale filtration. Journal of Agricultural and Food Chemistry 67 (9):2670-2678.

Redan, B. W., and L. S. Jackson. 2020. Overview of the American Chemical Society symposium on metals and trace elements in food safety, health, and food quality. Journal of Agricultural and Food Chemistry. doi: 10.1021/acs.jafc.0c01763.

Redan, B. W., J. A. Vinson, and M. G. Coco, Jr. 2013. Effect of thermal processing on free and total phenolics in nine varieties of common beans. International Journal of Food Sciences and Nutrition 64 (2):243-7.

Rüfer, C. E., J. Moeseneder, K. Briviba, G. Rechkemmer, and A. Bub. 2008. Bioavailability of astaxanthin stereoisomers from wild (Oncorhynchus spp.) and aquacultured (Salmo salar) salmon in healthy men: a randomised, double-blind study. British Journal of Nutrition 99 (5):1048-1054.

Rupérez, P. 2002. Mineral content of edible marine seaweeds. Food Chemistry 79 (1):23-26.

Ryckebosch, E., C. Bruneel, R. Termote-Verhalle, K. Goiris, K. Muylaert, and I. Foubert. 2014. Nutritional evaluation of microalgae oils rich in omega-3 long chain polyunsaturated fatty acids as an alternative for fish oil. Food Chemistry 160:393-400. 
Ryckebosch, E., K. Muylaert, M. Eeckhout, T. Ruyssen, and I. Foubert. 2011. Influence of drying and storage on lipid and carotenoid stability of the microalga Phaeodactylum tricornutum. Journal of Agricultural and Food Chemistry 59 (20):11063-11069.

Safi, C., B. Zebib, O. Merah, P.-Y. Pontalier, and C. Vaca-Garcia. 2014. Morphology, composition, production, processing and applications of Chlorella vulgaris: A review. Renewable and Sustainable Energy Reviews 35:265-278.

Santiago, A., and R. Moreira. 2020. "Drying of edible seaweeds." In Sustainable Seaweed Technologies, 131-154. Amsterdam: Elsevier.

Santoso, J., Y. Yoshie, and T. Suzuki. 2004. "Polyphenolic compounds from seaweeds: Distribution and their antioxidative effect." In Developments in Food Science, 169-177. Elsevier.

Sarada, R., M. G. Pillai, and G. Ravishankar. 1999. Phycocyanin from Spirulina sp: influence of processing of biomass on phycocyanin yield, analysis of efficacy of extraction methods and stability studies on phycocyanin. Process Biochemistry 34 (8):795-801.

Schagerl, M., and G. Künzl. 2007. Chlorophyll a extraction from freshwater algae-A reevaluation. Biologia 62 (3):270-275.

Schiener, P., K. D. Black, M. S. Stanley, and D. H. Green. 2015. The seasonal variation in the chemical composition of the kelp species Laminaria digitata, Laminaria hyperborea, Saccharina latissima and Alaria esculenta. Journal of Applied Phycology 27 (1):363-373.

Schwenzfeier, A., P. A. Wierenga, and H. Gruppen. 2011. Isolation and characterization of soluble protein from the green microalgae Tetraselmis sp. Bioresource technology 102 (19):9121-9127.

Seshadri, C., B. Umesh, and R. Manoharan. 1991. Beta-carotene studies in Spirulina. Bioresource Technology 38 (2-3):111-113.

Shinwari, K. J., and P. S. Rao. 2018a. Stability of bioactive compounds in fruit jam and jelly during processing and storage: A review. Trends in Food Science \& Technology 75:181-193.

Shinwari, K. J., and P. S. Rao. 2018b. Thermal-assisted high hydrostatic pressure extraction of nutraceuticals from saffron (Crocus sativus): Process optimization and cytotoxicity evaluation against cancer cells. Innovative Food Science \& Emerging Technologies 48:296-303.

Silva, A. F., H. Abreu, A. Silva, and S. M. Cardoso. 2019. Effect of Oven-Drying on the Recovery of Valuable Compounds from Ulva rigida, Gracilaria sp. and Fucus vesiculosus. Marine drugs 17 (2):90.

Simon, D., and S. Helliwell. 1998. Extraction and quantification of chlorophyll a from freshwater green algae. Water Research 32 (7):2220-2223.

Stévant, P., E. Indergård, A. Ólafsdóttir, H. Marfaing, W. E. Larssen, J. Fleurence, M. Y. Roleda, T. Rustad, R. Slizyte, and T. S. Nordtvedt. 2018. Effects of drying on the nutrient content and physico-chemical and sensory characteristics of the edible kelp Saccharina latissima. Journal of Applied Phycology 30 (4):2587-2599.

Stiger-Pouvreau, V., N. Bourgougnon, and E. Deslandes. 2016. "Carbohydrates from seaweeds." In Seaweed in health and disease prevention, 223-274. Elsevier.

Suzuki, J. Y., and C. E. Bauer. 1995. A prokaryotic origin for light-dependent chlorophyll biosynthesis of plants. Proceedings of the National Academy of Sciences 92 (9):3749-3753.

Talarico, L., C. Pujol, R. Zibetti, P. Faria, M. Noseda, M. Duarte, and E. Damonte. 2005. The antiviral activity of sulfated polysaccharides against dengue virus is dependent on virus serotype and host cell. Antiviral Research 66 (2-3):103-110. 
Tanna, B., and A. Mishra. 2018. Metabolites unravel nutraceutical potential of edible seaweeds: An emerging source of functional food. Comprehensive Reviews in Food Science and Food Safety 17 (6):1613-1624.

Taylor, V., B. Goodale, A. Raab, T. Schwerdtle, K. Reimer, S. Conklin, M. R. Karagas, and K. A. Francesconi. 2017. Human exposure to organic arsenic species from seafood. Science of the Total Environment 580:266-282.

Taylor, V., and B. Jackson. 2016. Concentrations and speciation of arsenic in New England seaweed species harvested for food and agriculture. Chemosphere 163:6-13.

Taylor, V. F., Z. Li, V. Sayarath, T. J. Palys, K. R. Morse, R. A. Scholz-Bright, and M. R. Karagas. 2017. Distinct arsenic metabolites following seaweed consumption in humans. Scientific Reports 7 (1):3920.

Tello-Ireland, C., R. Lemus-Mondaca, A. Vega-Gálvez, J. López, and K. Di Scala. 2011. Influence of hot-air temperature on drying kinetics, functional properties, colour, phycobiliproteins, antioxidant capacity, texture and agar yield of alga Gracilaria chilensis. LWT-Food Science and Technology 44 (10):2112-2118.

Terasaki, M., B. Narayan, H. Kamogawa, M. Nomura, N. M. Stephen, C. Kawagoe, M. Hosokawa, and K. Miyashita. 2012. Carotenoid profile of edible Japanese seaweeds: an improved HPLC method for separation of major carotenoids. Journal of Aquatic Food Product Technology 21 (5):468479.

Tokuşoglu, Ö., and M. Üunal. 2003. Biomass nutrient profiles of three microalgae: Spirulina platensis, Chlorella vulgaris, and Isochrisis galbana. Journal of Food Science 68 (4):1144-1148.

Unlu, N. Z., T. Bohn, D. M. Francis, H. N. Nagaraja, S. K. Clinton, and S. J. Schwartz. 2007. Lycopene from heat-induced cis-isomer-rich tomato sauce is more bioavailable than from all-trans-rich tomato sauce in human subjects. British Journal of Nutrition 98 (1):140-146.

Uribe, E., A. Vega-Gálvez, V. García, A. Pastén, J. López, and G. Goñi. 2019. Effect of different drying methods on phytochemical content and amino acid and fatty acid profiles of the green seaweed, Ulva spp. Journal of Applied Phycology 31 (3):1967-1979.

Uribe, E., A. Vega-Gálvez, V. Heredia, A. Pastén, and K. Di Scala. 2018. An edible red seaweed (Pyropia orbicularis): Influence of vacuum drying on physicochemical composition, bioactive compounds, antioxidant capacity, and pigments. Journal of Applied Phycology 30 (1):673-683.

US Food and Drug Administration. 2018. "Metals." Last Modified 21 Sept 2018, accessed 24 Nov 2019. https://www.fda.gov/Food/FoodborneIllnessContaminants/Metals/default.htm.

Uy, S. F., A. J. Easteal, M. M. Farid, R. B. Keam, and G. T. Conner. 2005. Seaweed processing using industrial single-mode cavity microwave heating: A preliminary investigation. Carbohydrate Research 340 (7):1357-1364.

van den Berg, H., L. Brandsen, and B. J. Sinkeldam. 1991. Vitamin B-12 content and bioavailability of spirulina and nori in rats. Journal of Nutritional Biochemistry 2 (6):314-318.

Varapasad, D., N. R. Sudha, S. N. Parveen, and T. Chandrasekhar. 2019. Effect of various solvents on chlorophyll and carotenoid extraction in green algae: Chlamydomonas reinhardtii and Chlorella vulgaris. Annals of Plant and Soil Research 21 (4):341-345.

Wachtel-Galor, S., K. W. Wong, and I. F. Benzie. 2008. The effect of cooking on Brassica vegetables. Food Chemistry 110 (3):706-710. 
Wang, C., H.-Y. Duan, and J.-W. Teng. 2014. Assessment of microwave cooking on the bioaccessibility of cadmium from various food matrices using an in vitro digestion model. Biological Trace Element Research 160 (2):276-284.

Wang, J., M. Zhang, and Z. Fang. 2019. Recent development in efficient processing technology for edible algae: a review. Trends in Food Science \& Technology.

Wells, M. L., P. Potin, J. S. Craigie, J. A. Raven, S. S. Merchant, K. E. Helliwell, A. G. Smith, M. E. Camire, and S. H. Brawley. 2017. Algae as nutritional and functional food sources: revisiting our understanding. Journal of Applied Phycology 29 (2):949-982.

Wolle, M. M., and S. D. Conklin. 2018. Speciation analysis of arsenic in seafood and seaweed: Part IEvaluation and optimization of methods. Analytical and Bioanalytical Chemistry:1-13.

Zava, T. T., and D. T. Zava. 2011. Assessment of Japanese iodine intake based on seaweed consumption in Japan: a literature-based analysis. Thyroid Research 4 (1):14. 